\title{
Ruminal bacterial community shifts in grain-, sugar-, and histidine-challenged dairy heifers
}

\author{
H. M. Golder, ${ }^{*} \dagger^{1}$ S. E. Denman, $\ddagger$ C. McSweeney, $¥$ P. Celi, ${ }^{*} \S$ and I. J. Lean ${ }^{*} \dagger$ \\ *Dairy Science Group, Faculty of Veterinary Science, The University of Sydney, Camden, New South Wales, Australia 2570 \\ †SBScibus, Camden, New South Wales, Australia 2570 \\ ¥CSIRO Animal, Food and Health Services, Queensland Bioscience Precinct, St. Lucia, Queensland, Australia 4067 \\ §Melbourne School of Land and Environment, The University of Melbourne, Parkville, Victoria, Australia 3052
}

\begin{abstract}
Ruminal bacterial community composition (BCC) and its associations with ruminal fermentation measures were studied in dairy heifers challenged with combinations of grain, fructose, and histidine in a partial factorial study. Holstein-Friesian heifers $(\mathrm{n}=30)$ were randomly allocated to 5 triticale grain-based treatment groups: (1) control (no grain), (2) grain [fed at a dry matter intake (DMI) of $1.2 \%$ of body weight (BW)], (3) grain $(0.8 \%$ of BW DMI $)+$ fructose $(0.4 \%$ of BW DMI), (4) grain $(1.2 \%$ of BW DMI $)+$ histidine $(6 \mathrm{~g} /$ head), and (5) grain (0.8\% of BW DMI) + fructose $(0.4 \%$ of BW DMI $)+$ histidine $(6 \mathrm{~g} /$ head $)$. Ruminal fluid was collected using a stomach tube 5,115 , and 215 min after consumption of the rations and bacterial $16 \mathrm{~S}$ ribosomal DNA sequence data was analyzed to characterize bacteria. Large variation among heifers and distinct BCC were evident in a between-group constrained principal components analysis. Bacterial composition in the fructose-fed heifers was positively related to total lactate and butyrate concentrations. Bacterial composition was positively associated with ruminal ammonia, valerate, and histamine concentrations in the grain-fed heifers. The predominant phyla were the Firmicutes (57.6\% of total recovered sequences), Bacteroidetes $(32.0 \%)$, and candidate phylum TM7 (4.0\%). Prevotella was the dominant genus. In general, grain or histidine or their interactions with time had minimal effects on the relative abundance of bacterial phyla and families. Fructose increased and decreased the relative abundance of the Firmicutes and Proteobacteria phyla over time, respectively, and decreased the abundance of the Prevotellaceae family over time. The relative abundance of the Streptococcaceae and Veillonellaceae families was increased in the fructose-fed heifers and these heifers over time. A total of 31 operational taxonomic units differed among treatment groups in the $3.6 \mathrm{~h}$ sampling
\end{abstract}

Received January 31, 2014.

Accepted April 10, 2014.

${ }^{1}$ Corresponding author: heleng@sbscibus.com.au period, Streptococcus bovis was observed in fructose fed animals. The TM7 candidate phylum had an increased abundance of sequence reads by over 2.5 fold due to the introduction of histidine into the diet. Rapid changes in $\mathrm{BCC}$ can occur in a short period after a single substrate challenge and the nature of these changes may influence ruminal acidosis risk and differ from those in cattle exposed to substrate challenges over a longer time period. Key words: bacterial community composition, fructose, histidine, ruminal acidosis

\section{INTRODUCTION}

The rumen ecosystem is highly responsive to dietary changes, most notably those that occur during weaning and shifts from forage- to concentrate-based diets (Tajima et al., 2000). Examples of marked dietary change occur at the transition period in dairy systems or induction of beef cattle to feedlot diets. These abrupt changes in diet can be associated with ruminal acidosis, a complex of ruminal conditions with a significant economic impact (Stone, 1999). The complex occurs along a continuum of severity, reflected in increased disease and losses in production performance. The prevalence of ruminal acidosis has been reported as approximately $20 \%$ in Wisconsin dairy herds (Oetzel et al., 1999), 10\% in Australian herds (Bramley et al., 2008), and 11\% in Irish herds (O'Grady et al., 2008). Bramley et al. (2008) found diets with high NFC and low NDF increased the risk of ruminal acidosis, a condition associated with increased ruminal propionate, valerate, butyrate, and acetate and decreased ammonia concentrations and lower milk fat-to-protein ratio.

Feeding different substrates alters ruminal fermentation responses (Heldt et al., 1999; Golder et al., 2012), presumably partly resulting from different responses in bacterial community composition (BCC) in the rumen. Researchers have examined ruminal bacterial composition changes among cattle fed forage- and concentratebased diets (Tajima et al., 2000; Petri et al., 2012), cattle fed increasing dietary percentages of concentrate (Callaway et al., 2010; Fernando et al., 2010), or in 
cattle with induced subacute acidosis (Khafipour et al., 2009; Hook et al., 2011). However, these studies have used relatively small numbers of cattle and focused on changes that occurred after adaptation to feed changes. Others have suggested that the rumen microbiome is reasonably resistant to dietary changes (Weimer et al., 2010) and a change in the microbiome is not always related to the severity of ruminal acidosis (Mohammed et al., 2012).

Golder et al. (2012) hypothesized that the addition of $0.4 \%$ of BW fructose or histidine ( $6 \mathrm{~g}$ per head), or both, to grain fed as a single challenge would increase the onset of SARA. The rationale for this hypothesis is that fructose is rapidly metabolized compared with starch (Firkins, 2011) and metabolic acidosis was induced in heifers drenched with 13, 17, or $21 \mathrm{~g} / \mathrm{kg}$ $(\sim 0.13,0.17$, and $0.21 \%$ of $\mathrm{BW})$ of oligofructose, a polymer of fructose (Thoefner et al., 2004). Ruminal and systemic acidosis were also induced when $17 \mathrm{~g} / \mathrm{kg}$ $(\sim 0.17 \%$ of $\mathrm{BW})$ of oligofructose was administered to heifers (Danscher et al., 2009; 2010). With increased interest in potential benefits of Lolium perenne varieties with greater water-soluble carbohydrate content in pasture-based dairying (Miller et al., 2001; Tas et al., 2006 ), it is important to assess the role of sugars in the development of acidosis. The concentration of fructose fed by Golder et al. (2012; $0.4 \%$ of BW) is similar to concentrations of water-soluble carbohydrates ingested by cattle over a day.

Release of histamine has been hypothesized to have an important role in acidosis (Dain et al., 1955; Ahrens, 1967), as has endotoxin release (Gozho et al., 2005; Khafipour et al., 2009). The amino acid histidine is decarboxylated at low rumen $\mathrm{pH}$ by the bacteria $\mathrm{Al}$ lisonella histaminiformans to produce the inflammatory molecule histamine (Garner et al., 2002). The rationale for use of histidine in the study was based on the relatively high concentrations in white clovers, ryegrass, and kikuyu (Reeves et al., 1996; Penkov et al., 2003). Providing fructose and histidine in combination may have a different influence on BCC and subsequent rumen fermentation measures compared with when they are fed in isolation.

Golder et al. (2012) found that a grain challenge decreased ruminal $\mathrm{pH}$ and increased ammonia, total VFA, acetate, butyrate, propionate, and valerate concentrations compared with the controls fed no grain. Fructose fed at $0.4 \%$ of $\mathrm{BW}$ decreased ruminal $\mathrm{pH}$ and valerate concentrations, increased total VFA and butyrate concentrations, and markedly increased D- and L-lactate concentrations compared with non-fructose-fed heifers. Histidine had limited effects on ruminal fermentation. Combinations of grain, fructose, and histidine had no effects on ruminal endotoxin and plasma oxidative stress biomarker concentrations (Golder et al., 2013). It was concluded that the fructose-fed heifers were at the highest risk of SARA.

The aim of this study was to examine the effects of combinations of grain, fructose, and histidine, fed to dairy heifers unadapted to these in a single challenge, on ruminal $\mathrm{BCC}$ and its associations with ruminal fermentation measures. We hypothesized that distinct bacterial communities would begin to develop over $3.6 \mathrm{~h}$ after the single challenge feeding among heifers fed combinations of grain, fructose, and histidine and reflect ruminal fermentation measures. We wished to evaluate responses in the context of the existing understanding of ruminal acidosis models commonly presented (Owens et al., 1998; Nagaraja and Titgemeyer, 2007; RAGFAR, 2007).

\section{MATERIALS AND METHODS}

\section{Animals and Experimental Design}

The experiment was conducted on 30 nonpregnant Holstein heifers $<18$ mo of age $(359.3 \pm 47.3 \mathrm{~kg}$ of BW) at Camden, New South Wales (NSW), Australia. All experimental procedures were approved by the Bovine Research Australasia Animal Ethics Committee (BRA 0609-0610). The experiment consisted of a 10-d adaptation period followed by a single-pulse feeding challenge on d 11. All heifers were housed on a dry lot and fed twice daily on a feed pad with individual head stanchions. During the adaptation period, the heifers were fed $1 \mathrm{~kg}$ (as fed) of grain daily and a target intake of $7.2 \mathrm{~kg}$ of alfalfa hay/d and $2 \mathrm{~kg}$ of ryegrass silage/d (as-fed basis). Rumen and blood samples were collected over approximately a 3.6 -h period after consumption of the challenge rations. Dietary information, experimental detail, and ruminal fermentation products, ruminal $\mathrm{pH}$, endotoxin, and oxidative stress results have been reported previously (Golder et al., 2012, 2013). This article provides data on BCC and interprets other findings in this context.

\section{Treatment Groups}

As described by Golder et al. (2012), 30 HolsteinFriesian heifers ( $\mathrm{n}=6$ heifers/group) were randomly assigned to 5 treatment groups in a partial factorial arrangement: (1) control (no grain), (2) grain (fed at a crushed grain DMI of $1.2 \%$ of $\mathrm{BW}),(3)$ grain $(0.8 \%$ of BW DMI) + fructose (0.4\% of BW DMI), (4) grain $(1.2 \%$ of BW DMI $)+$ histidine $(6 \mathrm{~g} /$ head $)$, and (5) grain $(0.8 \%$ of BW DMI $)+$ fructose $(0.4 \%$ of BW DMI $)+$ histidine $(6 \mathrm{~g} / \mathrm{head})$. The chemical composition of the grain, triticale cultivar Berkshire, was analyzed by wet 
Table 1. Estimated chemical composition of the challenge rations ${ }^{1}$

\begin{tabular}{|c|c|c|c|c|c|}
\hline \multirow{2}{*}{$\begin{array}{l}\text { Item (\% of DM, } \\
\text { unless otherwise specified) }\end{array}$} & \multicolumn{5}{|c|}{ Treatment group ${ }^{2,3}$} \\
\hline & Control & GR & $\mathrm{GR}+\mathrm{FR}$ & GR + HIS & $\mathrm{GR}+\mathrm{FR}+\mathrm{HIS}$ \\
\hline $\mathrm{DM}(\%)$ & 87.7 & 88.8 & 88.8 & 91.5 & 91.5 \\
\hline $\mathrm{CP}$ & 20.7 & 16.9 & 17.1 & 11.5 & 11.7 \\
\hline RUP (\% of CP) & 23.5 & 12.9 & 14.2 & 12.8 & 14.8 \\
\hline RDP (\% of CP) & 76.5 & 87.2 & 85.8 & 87.2 & 85.2 \\
\hline RDP & 15.8 & 14.7 & 14.6 & 10.0 & 10.0 \\
\hline Soluble protein ( $\%$ of $\mathrm{CP}$ ) & 43.0 & 27.3 & 28.4 & 27.7 & 29.3 \\
\hline $\mathrm{ADF}$ & 33.6 & 6.43 & 6.41 & 4.74 & 4.72 \\
\hline NDF & 45.9 & 23.1 & 23.0 & 16.0 & 15.9 \\
\hline Forage NDF ( $\%$ of NDF) & 100.0 & 7.96 & 7.96 & 11.5 & 11.5 \\
\hline Forage NDF ( $\%$ of DM) & 45.9 & 1.84 & 1.83 & 1.84 & 1.83 \\
\hline Physically effective NDF & 41.3 & 10.1 & 10.1 & 7.31 & 7.29 \\
\hline Lignin & 6.80 & 2.48 & 2.47 & 1.74 & 1.74 \\
\hline $\mathrm{NFC}^{4}$ & 25.4 & 56.5 & 56.4 & 70.0 & 69.8 \\
\hline Silage acids & 0.00 & 0.00 & 0.00 & 0.00 & 0.00 \\
\hline Sugar & 4.90 & 3.84 & 3.83 & 34.6 & 34.5 \\
\hline Starch & 2.50 & 49.7 & 49.6 & 33.2 & 33.2 \\
\hline Soluble fiber & 18.0 & 2.91 & 2.90 & 2.21 & 2.21 \\
\hline Total ether extract & 2.50 & 1.54 & 1.53 & 1.06 & 1.06 \\
\hline Total $\mathrm{LCFA}^{5}$ & 1.38 & 1.36 & 1.35 & 0.92 & 0.92 \\
\hline Ash & 9.00 & 2.66 & 2.66 & 1.90 & 1.89 \\
\hline $\mathrm{DCAD}(\mathrm{mEq} / 100 \mathrm{~g})$ & 35.8 & 3.03 & -0.42 & 2.50 & -0.95 \\
\hline \multicolumn{6}{|l|}{ Mineral $(\mathrm{mg} / \mathrm{kg})$} \\
\hline Chloride & 9,400 & 1,700 & 1,700 & 1,300 & 1,300 \\
\hline Calcium & 10,000 & 3,800 & 3,800 & 2,700 & 2,700 \\
\hline Phosphorus & 3,400 & 3,000 & 3,000 & 2,100 & 2,000 \\
\hline Potassium & 24,200 & 7,300 & 7,300 & 5,200 & 5,200 \\
\hline Magnesium & 2,900 & 1,400 & 1,400 & 900 & 900 \\
\hline Sodium & 4,400 & 300 & 300 & 200 & 200 \\
\hline Sulfur & 3,000 & 1,900 & 2,500 & 1,300 & 1,900 \\
\hline
\end{tabular}

${ }^{1}$ Estimations were performed using CPM Dairy Analyzer version 3.10 (Cornell-Penn-Miner, Cornell University, Ithaca, NY) using the chemical composition components of triticale cultivar Berkshire and alfalfa hay from Golder et al. (2012) and were based on the mean BW of the 30 heifers (360 kg) with a BCS of 3.25 (scale of 1 to 5) and growth rate of $0.91 \mathrm{~kg} / \mathrm{d}$.

${ }^{2}$ All challenge rations included $200 \mathrm{~g}$ (as fed) of alfalfa hay.

${ }^{3}$ Control (no grain); GR = grain (crushed triticale; $1.2 \%$ of BW DMI); GR + FR = grain $(0.8 \%$ of BW DMI) + fructose $(0.4 \%$ of BW DMI); GR + HIS = grain $(1.2 \%$ of BW DMI $)+$ histidine $(6 \mathrm{~g} /$ head $) ; \mathrm{GR}+\mathrm{FR}+$ HIS $=$ grain $(0.8 \%$ of BW DMI $)+$ fructose $(0.4 \%$ of BW DMI $)+$ histidine $(6 \mathrm{~g} / \mathrm{head})$.

${ }^{4}$ Nonfiber carbohydrates $=100-[(\mathrm{NDF}-\mathrm{NDICP})+\mathrm{CP}+$ crude fat + ash $]$, where NDICP $=$ neutral detergent-insoluble CP.

${ }^{5} \mathrm{LCFA}=$ long-chain FA.

chemistry (Golder et al., 2012). The fructose (Melbourne Food Depot, East Brunswick, Victoria, Australia) was a 99.5\% pure crystalline powder and was mixed through the grain ration on the morning of the challenge. The histidine was an L-histidine powder (Merck KGaA, Darmstadt, Germany) dissolved in $50 \mathrm{~mL}$ of tap water and was administered by a stomach tube. The challengeday rations had an estimated NFC content of 25.4, 56.5, $56.4,70.0$, and $69.8 \%$ of DM for control, grain, grain + histidine, grain + fructose, and grain + fructose + histidine groups, respectively (Table 1).

\section{Challenge and Ruminal Fluid Sampling Procedures}

Briefly, as described by Golder et al. (2012), all heifers were withheld from feed for $14 \mathrm{~h}$ before being indi- vidually offered $200 \mathrm{~g}$ of alfalfa hay to reduce salivation and immediately after its consumption were offered their respective challenge rations. Ruminal fluid (250 $\mathrm{mL}$ ) was collected by a stomach tube $5,65,115,165$, and 215 min after ration consumption and immediately scored for saliva contamination using the methodology of Bramley et al. (2008). Ruminal pH was immediately measured and samples of unfiltered ruminal fluid that was primarily liquid but contained particulate matter, thus representing a mixture of the liquid and particulate phases of the rumen, were put on ice and later stored in 5 - $\mathrm{mL}$ tubes at $-20^{\circ} \mathrm{C}$ for bacterial analysis. Ruminal $\mathrm{pH}$ values may be high in this study and reflect diets that do not contain silage and samples collected by stomach tube. Ruminal fluid was also processed and analyzed as described by Golder et al. (2012) for VFA, 
ammonia, D- and L-lactate, histamine, and endotoxin concentrations (Table 2).

\section{DNA Extraction}

Bacterial community composition was only determined on ruminal fluid collected 5, 115, and $215 \mathrm{~min}$ after consumption of the challenge rations. Ruminal fluid samples $(\mathrm{n}=90)$ were thawed at room temperature and a 1-mL aliquot was centrifuged at 10,000 $\times$ $g$ for $1 \mathrm{~min}$ and the supernatant discarded. The pellet was resuspended by vigorous vortexing in $200 \mu \mathrm{L}$ of animal tissue lysis (ATL) buffer (Qiagen $\mathrm{GmbH}$, Hilden, North Rhine-Westphalia, Germany) together with 200-mg silica-zirconium beads (1:1 mixture of 0.1and 1.0-mm beads; BioSpec Products Inc., Bartlesville, OK). The mixture was homogenized in a FastPrep-24 (MP Biomedicals Australasia Pty Ltd., Seven Hills, NSW, Australia) at maximum speed for 1 min (twice), heated at $70^{\circ} \mathrm{C}$ for $15 \mathrm{~min}$, and spun at $10,000 \times \mathrm{g}$ for 5 min. Supernatant $(180 \mu \mathrm{L})$ was removed for digestion with proteinase $\mathrm{K}$ at $50^{\circ} \mathrm{C}$ for at least $3 \mathrm{~h}$ and DNA was extracted according to the QIAamp DNA mini kit protocol (Qiagen $\mathrm{GmbH}$ ); DNA was quantified using a NanoDrop spectrophotometer ND-1000 (Thermo Scientific, Waltham, MA).

\section{PCR Amplification of 16S Ribosomal DNA Gene Sequences}

Genomic DNA from each sample was diluted 1:30 with water and the $16 \mathrm{~S}$ rRNA gene spanning V1 to V3 was PCR amplified using Platinum Taq polymerase (Invitrogen Corp., Carlsbad, CA) as follows: 1 cycle at $94^{\circ} \mathrm{C}$ for $2 \mathrm{~min} ; 30$ cycles of $94^{\circ} \mathrm{C}$ for $10 \mathrm{~s}, 55^{\circ} \mathrm{C}$ for 45 $\mathrm{s}$, and $72^{\circ} \mathrm{C}$ for $45 \mathrm{~s}$; with a final extension of $72^{\circ} \mathrm{C}$ for $10 \mathrm{~min}$. Primers used in the reaction were modified universal 8F (Snell-Castro et al., 2005) and 515R (Lane, 1991) primers that included 454 sequencing adapters $B$ and $\mathrm{A}$, respectively. In addition, a unique 8-bp barcode was included in the reverse primer of each amplicon, so that DNA sequence reads could be assigned accurately to each originating sample. The PCR products were visualized on agarose gels and equal amounts of PCR product were pooled and gel extracted (Qiaex gel extraction kit; Qiagen $\mathrm{GmbH}$ ). Approximately $3 \mu \mathrm{g}$ of pooled amplicon $(\sim 40 \mathrm{ng} / \mu \mathrm{L})$ was sent to Macrogen (Seoul, Korea) for 454 DNA sequencing using a 454 GS FLX Sequencer with titanium chemistry (Roche, Branford, CT).

\section{Sequence Analyses of Gene Amplicons}

Sequence data was processed using the quantitative insights into microbial ecology (QIIME) software pack- age (Caporaso et al., 2010). Recovered sequences were assigned to their originating sample based on the attached barcode and filtered based on quality and length parameters. Error correction of 454 sequences was performed using $\mathrm{R}$ software (package Acacia; Bragg et al., 2012). Clustering of recovered sequences to an operational taxonomic unit (OTU) at a 0.97 distance threshold was used. Taxonomic identification was based on similarity to the Greengenes Database (http:// greengenes.lbl.gov). The OTU table was subjected to $\alpha$ and $\beta$ diversity measures using QIIME and passed through R software (package ade4; Dray and Dufour, 2007) for principal components between-group analysis and co-inertia analysis.

\section{Statistical Analysis}

The relative abundances (raw means $\pm \mathrm{SD}$ ) of bacterial phyla and families from the 5 individual treatment groups are displayed in Table 3 . To obtain the predicted means \pm standard error of the mean, interactions, and main effects for the relative abundances of bacteria belonging to each phylum and family (Tables 4 and 5 , respectively), data from the 5 groups were merged and analyzed in a partial factorial arrangement using a linear mixed model in GenStat (14th edition; VSN International Ltd., Hemel, Hempstead, UK). The mean relative abundances of bacterial phyla or families that were $>0.3 \%$ for at least 1 group only were analyzed. The model used was as follows:

$$
\begin{aligned}
\mathrm{Y}_{\mathrm{ijklmn}}=\mu & +\alpha_{\mathrm{i}}+\beta_{(\mathrm{i}) \mathrm{j}}+\gamma_{(\mathrm{i}) \mathrm{k}}+\delta_{\mathrm{l}}+\delta_{(\mathrm{i}) \mathrm{jl}}+\delta_{(\mathrm{i}) \mathrm{kl}} \\
& +\mathrm{X}_{\mathrm{m}}+(\mathrm{XZ})_{\mathrm{mn}}+\varepsilon_{\mathrm{ijklmn}},
\end{aligned}
$$

where $Y_{\mathrm{ijklmn}}=$ response to grain $\mathrm{i}(\mathrm{i}=1$ or 2$)$, fructose $\mathrm{j}(\mathrm{j}=1$ or 2$)$, and histidine $\mathrm{k}(\mathrm{k}=1$ or 2$)$ at $\mathrm{l}$ time $(\mathrm{l}=$ 1 to 3$)$ from block $m(m=A$ to $D)$ by heifer $n(n=1$ to 30); $\mu=$ overall mean; $\alpha_{\mathrm{i}}=$ fixed effect of grain; $\beta_{(\mathrm{i}) \mathrm{j}}=$ fixed effect of fructose nested within grain; $\gamma_{(i) \mathrm{k}}=$ fixed effect of histidine nested within grain; $\delta_{1}=$ fixed effect of time; $\delta_{(\mathrm{i}) \mathrm{j}}=$ effect of fructose nested within grain by time interaction; $\delta_{(\mathrm{i}) \mathrm{kl}}=$ effect of histidine nested within grain by time interaction; $\mathrm{X}_{\mathrm{m}}=$ random effect of block; $(\mathrm{XZ})_{\mathrm{mn}}=$ random effect of heifer nested within block; and $\varepsilon_{\mathrm{ijklmn}}=$ random residual error within heifer $\mathrm{n}$ at time $\mathrm{l}$ from block $\mathrm{m}$. The covariance structure of the model was independent. The model was chosen following examination of other covariance structures, including autoregressive (AR1) structures. Minor differences only were observed between the independent and AR1 structures.

A false discovery rate (FDR) analysis was performed in R (package ade4) to identify OTU significantly in- 
Table 2. Least squares means $( \pm \mathrm{SEM})$ and effects and interactions of grain, fructose nested within grain, histidine nested within grain, and time for ruminal and plasma measures obtained from a merged factorial generalized linear model (adapted from Golder et al., 2012)

\begin{tabular}{|c|c|c|c|c|c|c|c|c|c|c|}
\hline \multirow[b]{3}{*}{ Item } & \multicolumn{6}{|c|}{ Group mean \pm SEM and $P$-value ${ }^{1}$} & \multicolumn{4}{|c|}{$P$-value } \\
\hline & \multicolumn{2}{|c|}{ Grain (G) } & \multicolumn{2}{|c|}{ Fructose $(\mathrm{F})$} & \multicolumn{2}{|c|}{ Histidine $(\mathrm{H})$} & \multirow[b]{2}{*}{ Time $(\mathrm{T})$} & \multicolumn{3}{|c|}{ Interaction } \\
\hline & - & + & - & + & - & + & & $\mathrm{G} \times \mathrm{T}$ & $\mathrm{F} \times \mathrm{T}$ & $\mathrm{H} \times \mathrm{T}$ \\
\hline $\begin{array}{l}\text { No. of animals } \\
\text { Rumen (m } M \text {, } \\
\text { unless otherwise specified) }\end{array}$ & 6 & 24 & 12 & 12 & 12 & 12 & & & & \\
\hline Total VFA & $63.7 \pm 5.1$ & $\begin{array}{c}95.9 \pm 2.6 \\
0.001\end{array}$ & $89.7 \pm 3.6$ & $\begin{array}{c}102.0 \pm 3.6 \\
0.021\end{array}$ & $96.7 \pm 3.6$ & $\begin{array}{c}95.0 \pm 3.6 \\
0.73\end{array}$ & 0.22 & 0.006 & 0.24 & 0.14 \\
\hline Acetate & $44.1 \pm 3.0$ & $\begin{array}{c}61.2 \pm 1.5 \\
0.001\end{array}$ & $58.3 \pm 2.2$ & $\begin{array}{c}64.1 \pm 2.2 \\
0.065\end{array}$ & $61.5 \pm 2.2$ & $\begin{array}{c}60.9 \pm 2.2 \\
0.85\end{array}$ & 0.19 & 0.013 & 0.13 & 0.19 \\
\hline ln butyrate ${ }^{2,3}$ & $1.83 \pm 0.1$ & $\begin{array}{c}2.50 \pm 0.1 \\
0.007\end{array}$ & $2.26 \pm 0.1$ & $\begin{array}{l}2.75 \pm 0.1 \\
\quad<0.001\end{array}$ & $2.50 \pm 0.1$ & $\begin{array}{c}2.50 \pm 0.1 \\
0.97\end{array}$ & 0.33 & 0.014 & 0.35 & 0.30 \\
\hline Isobutyrate & $1.21 \pm 0.1$ & $\begin{array}{c}1.21 \pm 0.1 \\
0.082\end{array}$ & $1.43 \pm 0.1$ & $\begin{array}{c}1.28 \pm 0.0 \\
<0.001\end{array}$ & $1.24 \pm 0.1$ & $\begin{array}{c}1.13 \pm 0.1 \\
0.25\end{array}$ & 0.40 & 0.035 & 0.16 & 0.074 \\
\hline Propionate & $8.73 \pm 0.9$ & $\begin{array}{c}15.27 \pm 0.5 \\
<0.001\end{array}$ & $14.63 \pm 0.6$ & $\begin{array}{c}15.91 \pm 0.6 \\
0.16\end{array}$ & $15.63 \pm 0.6$ & $\begin{array}{c}14.91 \pm 0.6 \\
0.43\end{array}$ & 0.079 & $<0.001$ & 0.21 & 0.051 \\
\hline ln caproate ch $^{2,3}$ & $-1.69 \pm 0.3$ & $\begin{array}{c}-0.90 \pm 0.2 \\
0.27\end{array}$ & $-1.13 \pm 0.2$ & $\begin{array}{c}-0.65 \pm 0.2 \\
0.11\end{array}$ & $-0.10 \pm 0.2$ & $\begin{array}{c}-0.79 \pm 0.2 \\
0.49\end{array}$ & 0.018 & 0.32 & 0.62 & 0.66 \\
\hline Valerate & $0.98 \pm 0.2$ & $\begin{array}{c}2.03 \pm 0.1 \\
<0.001\end{array}$ & $2.18 \pm 0.1$ & $\begin{array}{c}1.87 \pm 0.1 \\
0.042\end{array}$ & $1.95 \pm 0.1$ & $\begin{array}{c}2.10 \pm 0.1 \\
0.34\end{array}$ & $<0.001$ & $<0.001$ & 0.078 & 0.11 \\
\hline Isovalerate & $1.95 \pm 0.1$ & $\begin{array}{c}2.26 \pm 0.1 \\
0.013\end{array}$ & $2.53 \pm 0.1$ & $\begin{array}{l}2.00 \pm 0.9 \\
\quad<0.001\end{array}$ & $2.15 \pm 0.1$ & $\begin{array}{c}2.38 \pm 0.1 \\
0.083\end{array}$ & 0.51 & 0.011 & 0.13 & 0.004 \\
\hline ln D-lactate ${ }^{2,3}$ & $-2.13 \pm 0.5$ & $\begin{array}{c}0.59 \pm 0.3 \\
0.84\end{array}$ & $-2.14 \pm 0.4$ & $\begin{array}{l}0.97 \pm 0.4 \\
\quad<0.001\end{array}$ & $-0.44 \pm 0.4$ & $\begin{array}{c}-0.74 \pm 0.4 \\
0.55\end{array}$ & $<0.001$ & 0.87 & 0.090 & 0.44 \\
\hline ln L-lactate ${ }^{2,3}$ & $-2.87 \pm 0.4$ & $\begin{array}{c}-1.32 \pm 0.3 \\
0.77\end{array}$ & $-2.87 \pm 0.4$ & $\begin{array}{c}0.23 \pm 0.4 \\
<0.001\end{array}$ & $-1.17 \pm 0.4$ & $\begin{array}{c}1.47 \pm 0.4 \\
0.62\end{array}$ & 0.032 & 0.89 & 0.27 & 0.42 \\
\hline Ammonia & $8.28 \pm 1.0$ & $\begin{array}{c}12.30 \pm 0.5 \\
0.001\end{array}$ & $14.03 \pm 0.7$ & $\begin{array}{c}10.58 \pm 0.7 \\
0.003\end{array}$ & $11.95 \pm 0.7$ & $\begin{array}{c}12.66 \pm 0.7 \\
0.51\end{array}$ & $<0.001$ & 0.23 & 0.062 & 0.92 \\
\hline Histamine (ng/mL) & $61.3 \pm 18$ & $\begin{array}{r}114.5 \pm 9 \\
0.054\end{array}$ & $117.9 \pm 13$ & $\begin{array}{c}111.2 \pm 13 \\
0.71\end{array}$ & $105.5 \pm 13$ & $\begin{array}{c}123.6 \pm 13 \\
0.32\end{array}$ & $<0.001$ & 0.061 & 0.87 & 0.13 \\
\hline $\mathrm{pH}^{4}$ & $7.14 \pm 0.9$ & $\begin{array}{c}6.70 \pm 0.0 \\
0.030\end{array}$ & $6.92 \pm 0.1$ & $\begin{array}{c}6.49 \pm 0.1 \\
<0.001\end{array}$ & $6.67 \pm 0.1$ & $\begin{array}{c}6.74 \pm 0.1 \\
0.39\end{array}$ & 0.30 & 0.22 & 0.69 & 0.11 \\
\hline $\begin{array}{l}\text { Plasma } \\
\text { ln L-lactate }{ }^{2,3}(\mathrm{~m} M)\end{array}$ & $0.16 \pm 0.1$ & $\begin{array}{c}0.22 \pm 0.1 \\
0.86\end{array}$ & $0.23 \pm 0.1$ & $\begin{array}{c}0.21 \pm 0.1 \\
0.88\end{array}$ & $0.18 \pm 0.1$ & $\begin{array}{c}0.26 \pm 0.1 \\
0.54\end{array}$ & 0.001 & 0.030 & 0.58 & 0.66 \\
\hline ln histamine ${ }^{2,3}(\mathrm{ng} / \mathrm{mL})$ & $-1.55 \pm 0.2$ & $\begin{array}{c}-1.25 \pm 0.1 \\
0.550\end{array}$ & $-1.20 \pm 0.1$ & $\begin{array}{c}-1.30 \pm 0.1 \\
0.65\end{array}$ & $-1.43 \pm 0.1$ & $\begin{array}{c}-1.07 \pm 0.1 \\
0.104\end{array}$ & 0.003 & 0.12 & 0.19 & 0.009 \\
\hline $\begin{array}{l}{ }^{1} P \text {-values are for the compa } \\
{ }^{2} \text { ln }=\text { natural logarithm. } \\
{ }^{3} \text { Exponentiated least square } \\
0.12,0.55,0.12,2.64,0.64, \\
0.24 \text {, and } 0.34 .\end{array}$ & $\begin{array}{l}\text { of grain }(-/- \\
\text { ans for the } 6 \\
\text {.48; L-lactate: }\end{array}$ & $\begin{array}{l}\text { ), the compari } \\
\text { groups, respect } \\
0.06,0.27,0.06\end{array}$ & $\begin{array}{l}\text { fructose }(-/- \\
\text { butyrate: } 6.2 \\
0.31 \text {, and } 0.2\end{array}$ & $\begin{array}{l}\text { ested within } \\
\text { 2.18, 9.97, } 15 \\
\text { lasma L-lacta }\end{array}$ & $\begin{array}{l}\text { and the comp } \\
78 \text {, and } 12.1 \\
7,1.25,1.26\end{array}$ & $\begin{array}{l}\text { son of histidi } \\
\text { caproate: } 0.1 \\
3,1.20 \text {, and }\end{array}$ & $\begin{array}{l}\text { L } 0.32,0.5 \\
\text { lasma hista }\end{array}$ & $\begin{array}{l}\text { 2, } 0.90, \\
\text { amine: } 0\end{array}$ & $\begin{array}{l}\text { ain. } \\
\text { d } 0.45 \\
0.29\end{array}$ & $\begin{array}{l}\text {-lactate: } \\
\text { 30, 0.27, }\end{array}$ \\
\hline
\end{tabular}


Table 3. Relative abundance (raw mean \pm SD) of bacterial phyla and families for each treatment group

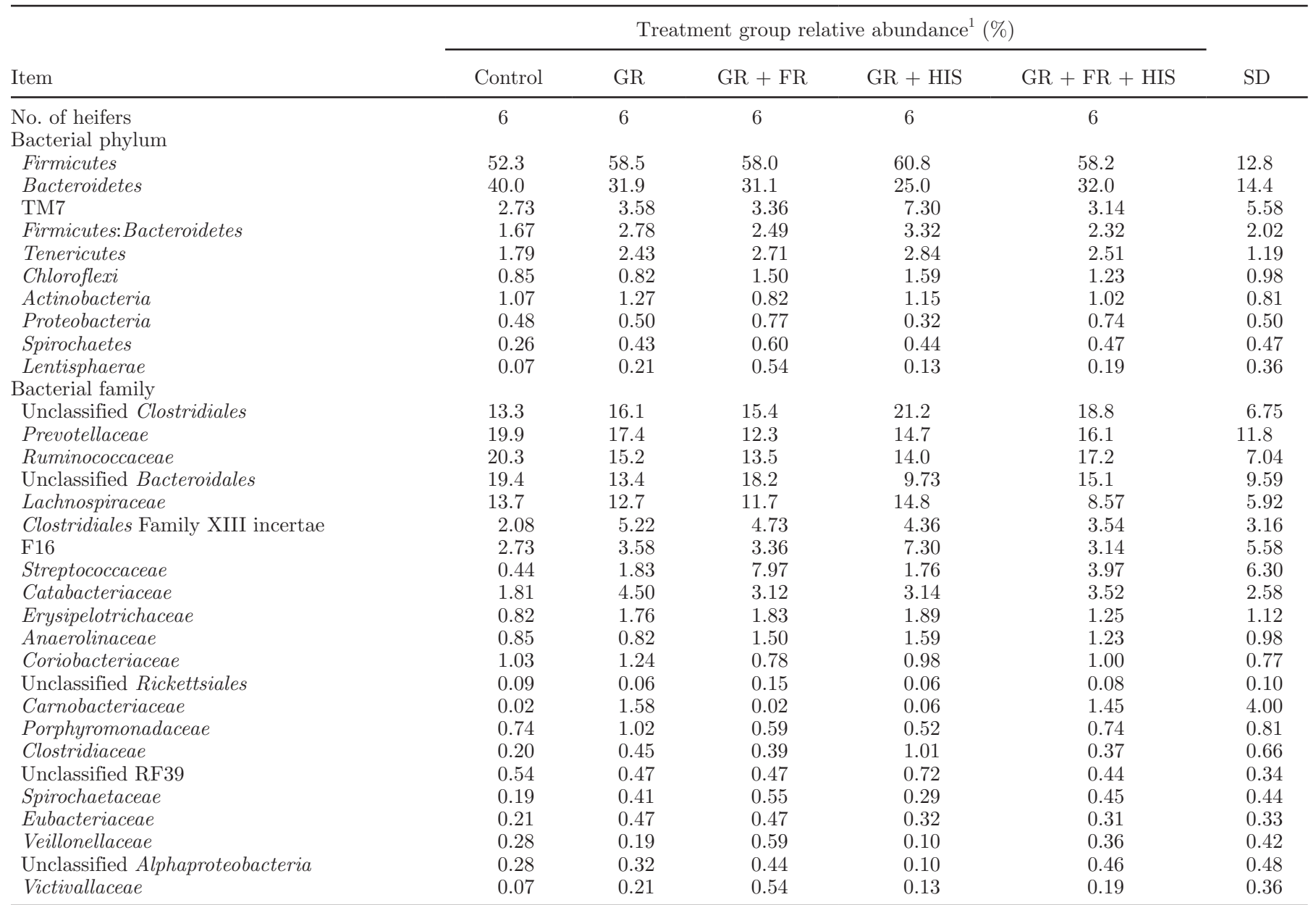

${ }^{1}$ Control (no grain); GR = grain (crushed triticale; $1.2 \%$ of BW DMI); GR + FR = grain $(0.8 \%$ of BW DMI $)+$ fructose $(0.4 \%$ of BW DMI); $\mathrm{GR}+\mathrm{HIS}=$ grain $(1.2 \%$ of BW DMI $)+$ histidine $(6 \mathrm{~g} /$ head $) ; \mathrm{GR}+\mathrm{FR}+\mathrm{HIS}=$ grain $(0.8 \%$ of BW DMI $)+$ fructose $(0.4 \%$ of BW DMI $)+$ histidine $(6 \mathrm{~g} / \mathrm{head})$.

fluenced among the 5 individual groups and these OTU were matched to the Greengenes Database and fitted into a phylogenetic tree using $\mathrm{R}$ software (package ARB; Ludwig et al., 2004).

\section{RESULTS}

\section{Bacterial Diversity Analysis}

Rarefaction analysis (Hughes et al., 2001), which is used to estimate the depth of coverage of diversity of ruminal bacteria within ruminal fluid samples (Kim et al., 2011), indicated that coverage of bacterial diversity appeared to be sufficient to evaluate BCC. Treatment group did not affect the general level of microbial diversity, with all samples possessing similar microbial diversity (Figure 1). The overall microbiomes of the heifers were not distinctly different in their composition either, with only 2.7 and $2.2 \%$ of the variance being explained, which could not be attributed to any of the treatment groups (data not shown). However, principal coordinates analysis (PCoA) revealed distinct variation $(P<0.001)$ in the $16 \mathrm{~S}$ ribosomal DNA (rDNA) estimated $\mathrm{BCC}$ among groups in a between-group constrained PCoA that accounted for a total of $53.8 \%$ of the variation (Figure 2).

Heifers from the control and grain + histidine treatment groups had the most distinct bacterial communities among the treatment groups (Figure 2). Heifers from the grain, grain + fructose, and grain + fructose + histidine treatment groups were closely clustered in the PCoA (Figure 2). A minor overlap in BCC occurred between the grain- and grain + fructose + histidinefed heifers. Spatial heterogeneity among heifers was relatively large and greatest in the grain + histidine heifers. Clustering of bacterial communities was similar for the 3 sample times within each treatment group and only a total of $22.7 \%$ of variation of the community was accounted for $(P=0.38$; data not shown $)$. 
Table 4. Predicted means \pm SEM and main effects and their interactions of grain, fructose nested within grain, histidine nested within grain, and time for bacterial phyla identified from $16 \mathrm{~S}$ ribosomal DNA recovered sequences with mean relative abundances of $>0.3 \%$ in at least 1 treatment group

\begin{tabular}{|c|c|c|c|c|c|c|c|c|c|c|}
\hline \multirow[b]{2}{*}{ Item } & \multicolumn{6}{|c|}{ Group mean relative abundance $(\%) \pm$ SEM and $P$-value ${ }^{1}$} & \multicolumn{4}{|c|}{$P$-value } \\
\hline & - & + & - & + & - & + & $\begin{array}{l}\text { Time } \\
(\mathrm{T})\end{array}$ & $\mathrm{G} \times \mathrm{T}$ & $\mathrm{F} \times \mathrm{T}$ & $\mathrm{H} \times \mathrm{T}$ \\
\hline No. of animals & 6 & 24 & 12 & 12 & 12 & 12 & & & & \\
\hline \multicolumn{11}{|l|}{ Bacterial phylum } \\
\hline Firmicutes & $52.3 \pm 3.6$ & $\begin{array}{c}58.9 \pm 1.9 \\
0.13\end{array}$ & $59.7 \pm 2.7$ & $\begin{array}{c}58.1 \pm 2.7 \\
0.68\end{array}$ & $58.2 \pm 2.7$ & $\begin{array}{c}59.5 \pm 2.7 \\
0.74\end{array}$ & 0.12 & 0.999 & 0.008 & 0.91 \\
\hline TM7 & $2.7 \pm 1.6$ & $\begin{array}{c}4.3 \pm 0.8 \\
0.35\end{array}$ & $5.4 \pm 1.1$ & $\begin{array}{c}3.2 \pm 1.1 \\
0.16\end{array}$ & $3.5 \pm 1.1$ & $\begin{array}{c}5.2 \pm 1.1 \\
0.26\end{array}$ & 0.59 & 0.59 & 0.20 & 0.21 \\
\hline Firmicutes:Bacteroidetes & $1.67 \pm 0.6$ & $\begin{array}{c}2.7 \pm 0.3 \\
0.10\end{array}$ & $3.0 \pm 0.4$ & $\begin{array}{c}2.4 \pm 0.4 \\
0.25\end{array}$ & $2.6 \pm 0.4$ & $\begin{array}{c}2.8 \pm 0.4 \\
0.75\end{array}$ & 0.28 & 0.83 & 0.003 & 0.25 \\
\hline Tenericutes & $1.79 \pm 0.4$ & $\begin{array}{c}2.6 \pm 0.2 \\
0.067\end{array}$ & $2.6 \pm 0.3$ & $\begin{array}{c}2.6 \pm 0.3 \\
0.95\end{array}$ & $2.6 \pm 0.3$ & $\begin{array}{c}2.7 \pm 0.3 \\
0.80\end{array}$ & 0.067 & 0.76 & 0.70 & 0.16 \\
\hline Spirochaetes & $0.27 \pm 0.2$ & $\begin{array}{c}0.5 \pm 0.1 \\
0.23\end{array}$ & $0.4 \pm 0.1$ & $\begin{array}{c}0.5 \pm 0.1 \\
0.53\end{array}$ & $0.5 \pm 0.1$ & $\begin{array}{c}0.5 \pm 0.1 \\
0.74\end{array}$ & 0.99 & 1.0 & 0.093 & 0.44 \\
\hline Lentisphaerae & $0.09 \pm 0.3$ & $\begin{array}{c}0.3 \pm 0.1 \\
0.072\end{array}$ & $0.2 \pm 0.1$ & $\begin{array}{c}0.4 \pm 0.1 \\
0.058\end{array}$ & $0.4 \pm 0.1$ & $\begin{array}{c}0.2 \pm 0.1 \\
0.030\end{array}$ & 0.15 & 0.91 & 0.29 & 0.19 \\
\hline
\end{tabular}

${ }^{1} P$-values are for the comparison of grain $(-/+)$, the comparison of fructose $(-/+)$ nested within grain, and the comparison of histidine $(-/+)$ nested within grain.

\section{Co-Inertia Analysis}

Co-inertia analysis explained associations among BCC, ruminal fermentation measures, and dietary inputs (Figure 3). Bacterial composition in the grain-fed cattle was associated with the amount of grain consumed and ruminal ammonia, valerate, and histamine concentrations. The amount of grain or fructose consumed had the largest influence on bacterial composition, and time of sampling the least. A strong positive relationship existed between bacterial composition in the 2 groups that consumed fructose and total lactate and butyrate concentrations (Figure 3).

\section{Bacteria Prevalence}

A total of 16 phyla and 1 candidate phylum were identified within the ruminal bacterial population from $16 \mathrm{~S}$ rDNA gene pyrosequences. The majority of recovered sequences were represented by the Firmicutes or Bacteroidetes phyla, accounting for a combined total of $90 \%$ of sequences: 58 and $32 \%$ of total recovered sequences, on average, respectively (data not shown). The candidate phylum TM7, represented $4.0 \%$ and the phylum Tenericutes represented $2.5 \%$ of the total recovered sequences, on average. The remaining microbiota were composed of phyla with low relative abundances $(<1.3 \%$ of total recovered sequences, on average) and were not present in heifers from all groups (data not shown). A total of 36 bacterial families were identified and the Prevotellaceae, Ruminococcaceae, and Lachnospiraceae families had the largest relative abundances: 16,16 , and $12 \%$, respectively (data not shown). However, the unclassified Clostridiales accounted for $17 \%$ of the total recovered sequences, on average, when the relative abundance of bacterial families was examined. The relative abundance of the Lactobacillaceae family was below our reported threshold. A total of 55 genera were identified. The Prevotella were the predominant genus and represented approximately $16 \%$ of the relative abundance of recovered bacterial sequences, ranging from an average of 13 to $21 \%$ among groups (data not shown). Escherichia, Megasphaera, and Allisonella were not identified during taxonomic assignment but may have been present and not assigned taxonomy.

Relative abundance results of ruminal bacterial phyla and families are displayed in Tables 4 and 5, respectively. These results include (1) the significance of the model interactions: grain, fructose nested within grain (fructose), and histidine nested within grain (histidine) $\times$ time; (2) the main effects of grain, fructose, and histidine; and (3) the predicted means \pm standard error of 
Table 5. Predicted means \pm SEM and main effects and their interactions of grain, fructose nested within grain, histidine nested within grain, and time for bacterial families identified from $16 \mathrm{~S}$ ribosomal DNA recovered sequences with mean relative abundances of $>0.3 \%$ in at least 1 treatment group

\begin{tabular}{|c|c|c|c|c|c|c|c|c|c|c|}
\hline \multirow[b]{3}{*}{ Item } & \multicolumn{6}{|c|}{ Group mean relative abundance $(\%) \pm \mathrm{SEM}$ and $P$-value ${ }^{1}$} & \multicolumn{4}{|c|}{$P$-value } \\
\hline & \multicolumn{2}{|c|}{ Grain $(G)$} & \multicolumn{2}{|c|}{ Fructose $(\mathrm{F})$} & \multicolumn{2}{|c|}{ Histidine $(\mathrm{H})$} & \multirow[b]{2}{*}{ Time $(\mathrm{T})$} & \multicolumn{3}{|c|}{ Interaction } \\
\hline & - & + & - & + & - & + & & $\mathrm{G} \times \mathrm{T}$ & $\mathrm{F} \times \mathrm{T}$ & $\mathrm{H} \times \mathrm{T}$ \\
\hline No. of animals & 6 & 24 & 12 & 12 & 12 & 12 & & & & \\
\hline \multicolumn{11}{|l|}{ Bacterial family } \\
\hline Unclassified Clostridiales & $13.3 \pm 1.6$ & $\begin{array}{c}17.9 \pm 1.0 \\
0.049\end{array}$ & $18.6 \pm 1.4$ & $\begin{array}{c}17.1 \pm 1.4 \\
0.46\end{array}$ & $15.8 \pm 1.4$ & $\begin{array}{c}20.0 \pm 1.4 \\
0.044\end{array}$ & 0.052 & 0.56 & 0.49 & 0.10 \\
\hline Prevotellaceae & $20.6 \pm 3.6$ & $\begin{array}{c}15.1 \pm 2.0 \\
0.29\end{array}$ & $16.1 \pm 2.8$ & $\begin{array}{c}14.2 \pm 2.8 \\
0.63\end{array}$ & $14.9 \pm 2.8$ & $\begin{array}{c}15.4 \pm 2.8 \\
0.89\end{array}$ & 0.71 & 0.11 & $<0.001$ & 0.95 \\
\hline Ruminococcaceae & $20.3 \pm 2.3$ & $\begin{array}{c}15.0 \pm 1.2 \\
0.055\end{array}$ & $14.6 \pm 1.7$ & $\begin{array}{c}15.4 \pm 1.7 \\
0.75\end{array}$ & $14.4 \pm 1.7$ & $\begin{array}{c}15.6 \pm 1.7 \\
0.60\end{array}$ & 0.12 & 0.034 & 0.66 & 0.65 \\
\hline Unclassified Bacteroidales & $19.6 \pm 2.8$ & $\begin{array}{c}14.4 \pm 1.8 \\
0.18\end{array}$ & $11.6 \pm 2.5$ & $\begin{array}{c}16.7 \pm 2.5 \\
0.15\end{array}$ & $15.8 \pm 2.5$ & $\begin{array}{c}12.5 \pm 2.5 \\
0.35\end{array}$ & 0.072 & 0.065 & 0.42 & 0.30 \\
\hline Lachnospiraceae & $13.5 \pm 2.2$ & $\begin{array}{c}11.9 \pm 1.5 \\
0.47\end{array}$ & $13.7 \pm 1.7$ & $\begin{array}{c}10.1 \pm 1.7 \\
0.064\end{array}$ & $12.4 \pm 1.8$ & $\begin{array}{c}11.4 \pm 1.8 \\
0.60\end{array}$ & 0.53 & 0.43 & 0.18 & 0.42 \\
\hline Clostridiales Family XIII incertae & $2.2 \pm 1.1$ & $\begin{array}{c}4.5 \pm 0.8 \\
0.039\end{array}$ & $4.8 \pm 0.9$ & $\begin{array}{c}4.2 \pm 0.9 \\
0.49\end{array}$ & $4.9 \pm 0.9$ & $\begin{array}{c}4.0 \pm 0.9 \\
0.37\end{array}$ & 0.047 & 0.68 & 0.21 & 0.70 \\
\hline F16 & $2.8 \pm 1.6$ & $\begin{array}{c}4.3 \pm 0.8 \\
0.35\end{array}$ & $5.4 \pm 1.1$ & $\begin{array}{c}3.3 \pm 1.1 \\
0.16\end{array}$ & $3.5 \pm 1.1$ & $\begin{array}{c}5.2 \pm 1.1 \\
0.26\end{array}$ & 0.58 & 0.59 & 0.21 & 0.21 \\
\hline Streptococcaceae & $0.6 \pm 1.7$ & $\begin{array}{c}3.9 \pm 0.8 \\
0.067\end{array}$ & $1.8 \pm 1.1$ & $\begin{array}{c}6.0 \pm 1.1 \\
0.016\end{array}$ & $4.9 \pm 1.1$ & $\begin{array}{c}2.9 \pm 1.1 \\
0.22\end{array}$ & 0.001 & 0.15 & 0.003 & 0.27 \\
\hline Catabacteriaceae & $1.7 \pm 0.8$ & $\begin{array}{c}3.6 \pm 0.4 \\
0.088\end{array}$ & $3.8 \pm 0.6$ & $\begin{array}{c}3.3 \pm 0.6 \\
0.58\end{array}$ & $3.8 \pm 0.6$ & $\begin{array}{c}3.3 \pm 0.6 \\
0.59\end{array}$ & 0.85 & 0.45 & 0.82 & 0.47 \\
\hline Erysipelotrichaceae & $0.8 \pm 0.4$ & $\begin{array}{c}1.7 \pm 0.2 \\
0.046\end{array}$ & $1.8 \pm 0.3$ & $\begin{array}{c}1.5 \pm 0.3 \\
0.44\end{array}$ & $3.8 \pm 0.3$ & $\begin{array}{c}1.6 \pm 0.3 \\
0.55\end{array}$ & 0.94 & 0.96 & 0.81 & 0.40 \\
\hline Anaerolinaceae & $0.9 \pm 0.3$ & $\begin{array}{c}1.3 \pm 0.2 \\
0.52\end{array}$ & $1.2 \pm 0.3$ & $\begin{array}{c}1.4 \pm 0.3 \\
0.76\end{array}$ & $1.1 \pm 0.3$ & $\begin{array}{c}1.5 \pm 0.3 \\
0.045\end{array}$ & 0.23 & 0.45 & 0.57 & 0.11 \\
\hline Coriobacteriaceae & $1.0 \pm 0.2$ & $\begin{array}{c}1.0 \pm 0.1 \\
0.99\end{array}$ & $1.1 \pm 0.2$ & $\begin{array}{c}0.9 \pm 0.2 \\
0.31\end{array}$ & $1.0 \pm 0.2$ & $\begin{array}{c}1.0 \pm 0.2 \\
0.71\end{array}$ & 0.004 & 0.11 & 0.036 & 0.84 \\
\hline Unclassified Rickettsiales & $0.1 \pm 0.0$ & $\begin{array}{c}0.9 \pm 0.0 \\
0.92\end{array}$ & $0.1 \pm 0.0$ & $\begin{array}{c}0.1 \pm 0.0 \\
0.025\end{array}$ & $0.1 \pm 0.0$ & $\begin{array}{c}0.1 \pm 0.0 \\
0.17\end{array}$ & 0.20 & 0.028 & $<0.001$ & 0.68 \\
\hline Carnobacteriaceae & $0.1 \pm 1.0$ & $\begin{array}{c}0.8 \pm 0.7 \\
0.54\end{array}$ & $0.8 \pm 0.8$ & $\begin{array}{c}0.7 \pm 0.8 \\
0.93\end{array}$ & $0.7 \pm 0.9$ & $\begin{array}{c}0.9 \pm 0.9 \\
0.86\end{array}$ & 0.13 & 0.60 & 0.99 & 0.999 \\
\hline Porphyromonadaceae & $0.8 \pm 0.3$ & $\begin{array}{c}0.7 \pm 0.2 \\
0.93\end{array}$ & $0.8 \pm 0.2$ & $\begin{array}{c}0.7 \pm 0.2 \\
0.73\end{array}$ & $0.8 \pm 0.2$ & $\begin{array}{c}0.6 \pm 0.2 \\
0.57\end{array}$ & $<0.001$ & 0.89 & 0.63 & 0.43 \\
\hline Clostridiaceae & $0.2 \pm 0.2$ & $\begin{array}{c}0.6 \pm 0.1 \\
0.19\end{array}$ & $1.1 \pm 0.2$ & $\begin{array}{c}0.4 \pm 0.2 \\
0.16\end{array}$ & $1.0 \pm 0.2$ & $\begin{array}{c}0.7 \pm 0.2 \\
0.27\end{array}$ & 0.13 & 0.86 & 0.70 & 0.44 \\
\hline Unclassified RF39 & $0.5 \pm 0.1$ & $\begin{array}{c}0.5 \pm 0.1 \\
0.91\end{array}$ & $0.6 \pm 0.1$ & $\begin{array}{c}0.5 \pm 0.1 \\
0.13\end{array}$ & $0.5 \pm 0.1$ & $\begin{array}{c}0.6 \pm 0.1 \\
0.31\end{array}$ & 0.003 & 0.064 & 0.59 & 0.19 \\
\hline Spirochaetaceae & $0.2 \pm 0.2$ & $\begin{array}{c}0.4 \pm 0.1 \\
0.15\end{array}$ & $0.3 \pm 0.1$ & $\begin{array}{c}0.5 \pm 0.1 \\
0.32\end{array}$ & $0.5 \pm 0.1$ & $\begin{array}{c}0.4 \pm 0.1 \\
0.36\end{array}$ & 0.81 & 0.98 & 0.22 & 0.67 \\
\hline Eubacteriaceae & $0.2 \pm 0.1$ & $\begin{array}{c}0.4 \pm 0.0 \\
0.071\end{array}$ & $0.4 \pm 0.1$ & $\begin{array}{c}0.4 \pm 0.1 \\
0.92\end{array}$ & $0.5 \pm 0.1$ & $\begin{array}{c}0.3 \pm 0.1 \\
0.086\end{array}$ & 0.24 & 0.35 & 0.10 & 0.11 \\
\hline Veillonellaceae & $0.3 \pm 0.1$ & $\begin{array}{c}0.3 \pm 0.1 \\
0.91\end{array}$ & $0.1 \pm 0.1$ & $\begin{array}{c}0.5 \pm 0.1 \\
0.005\end{array}$ & $0.4 \pm 0.1$ & $\begin{array}{c}0.2 \pm 0.1 \\
0.20\end{array}$ & 0.021 & 0.86 & 0.071 & 0.54 \\
\hline Unclassified Alphaproteobacteria & $0.3 \pm 0.1$ & $\begin{array}{c}0.3 \pm 0.1 \\
0.81\end{array}$ & $0.2 \pm 0.1$ & $\begin{array}{c}0.5 \pm 0.1 \\
0.16\end{array}$ & $0.4 \pm 0.1$ & $\begin{array}{c}0.3 \pm 0.1 \\
0.57\end{array}$ & 0.14 & 0.39 & 0.20 & 0.012 \\
\hline Victivallaceae & $0.1 \pm 0.1$ & $\begin{array}{c}0.3 \pm 0.1 \\
0.073\end{array}$ & $0.2 \pm 0.1$ & $\begin{array}{c}0.4 \pm 0.1 \\
0.046\end{array}$ & $0.4 \pm 0.1$ & $\begin{array}{c}0.2 \pm 0.1 \\
0.031\end{array}$ & 0.14 & 0.92 & 0.24 & 0.20 \\
\hline
\end{tabular}


the mean for the main effects. Results are only displayed for ruminal bacterial phyla or families that have relative abundances of $>0.3 \%$ in at least 1 group. Predicted means of relative abundances \pm standard error of the mean for all ruminal bacterial phyla and families that have significant $(P<0.001)$ interactions $\times$ time are graphed in Figures 4 and 5, respectively. Within- and among-group variation in relative abundance was high for several bacterial phyla and families, which reduced the number of significant effects (Tables 4 and 5).

The relative abundance of bacterial phyla was not influenced in grain-fed heifers over time compared with control heifers (Table 4). Grain also had no main effect on the relative abundance of bacterial phyla compared with controls. However, the relative abundance of the Bacteroidetes $(P=0.052)$ and Tenericutes $(P=$ $0.067)$ approached a significant decrease and increase, respectively, in grain-fed heifers compared with control heifers (Table 4). Time did not influence the relative abundance of bacterial phyla, with the exception of a trend toward an increase in the relative abundance of the Tenericutes $(P=0.067)$ at the 115 - compared with the 5 - and 215-min samplings (Table 4 ).

The relative abundance of the Firmicutes, Bacteroidetes, ratio of Firmicutes to Bacteroidetes, Actinobacteria, and Proteobacteria changed over time in the fructosecompared with non-fructose-fed heifers (Table 4; Figure $4 \mathrm{~A}$ to E, respectively). Fructose tended to increase the relative abundance of the Lentisphaerae compared with the relative abundance in the non-fructose-fed heifers $(P=0.058$; Table 4$)$.

The Proteobacteria were the only bacterial phylum that was influenced in relative abundance in the histidine- compared with non-histidine-fed heifers over time (Table 4; Figure 4F). The relative abundance of the Lentisphaerae was decreased in the histidine- compared with the non-histidine-fed heifers, whereas the relative abundance of other bacterial phyla was not influenced among these groups (Table 4).

The relative abundance of the Ruminococcaceae and the unclassified Rickettsiales differed over time in the grain-fed compared with control heifers (Table 5; Figure 5A and E). Grain-fed heifers had an increased relative abundance of the bacterial families, unclassified Clostridiales, Clostridiales Family XII incertae, and Erysipelotrichaceae, and tended to increase $(P=$ 0.067) the relative abundance of the Streptococcaceae compared with the control heifers (Table 5).

The relative abundance of the Clostridiales Family XII incertae, Streptococcaceae, and Veillonellaceae families increased over time, whereas that of the unclassified RF39 decreased. The relative abundance of the Porphyromonadaceae family increased in relative

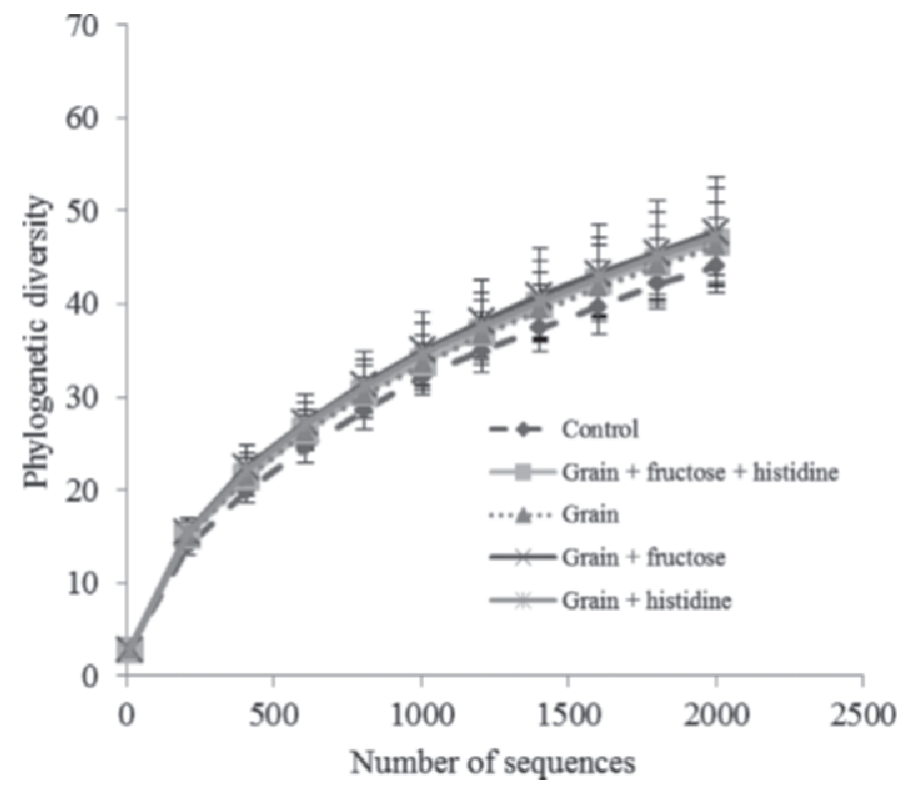

Figure 1. Rarefaction curves for each treatment group shown as the mean $\pm 95 \%$ CI. Phylogenetic diversity is shown in branch lengths on the $y$-axis and the number of recovered sequences sampled on the $\mathrm{x}$-axis.

abundance at the 115- compared with the 5- and 215min samplings (Table 5).

The relative abundance of the Prevotellaceae and $\mathrm{Co}$ riobacteriaceae families and the unclassified Rickettsiales was influenced over time in the fructose-fed heifers compared with the non-fructose-fed heifers (Table 5; Figure 5B to D). The relative abundance of the Streptococcaceae, Veillonellaceae, and Victivallaceae families increased in the fructose- compared with non-fructosefed heifers and tended to decrease in the Lachnospiraceae family $(P=0.064$; Table 5$)$.

The unclassified Alphaproteobacteria was the only bacterial family that was influenced in relative abundance over time in the histidine-fed heifers compared with the non-histidine-fed heifers (Table 5; Figure 5F). The relative abundance of the unclassified Clostridiales and Anaerolinaceae was increased in the histidine- compared with the non-histidine-fed heifers, and decreased in the Victivallaceae family compared with the nonhistidine-fed heifers (Table 5).

A total of 31 OTU were identified based on their relative abundance as being significantly associated with a treatment group using ANOVA and corrected with the FDR method. The similarity percentage of these OTU to known bacteria in the Greengenes Database from the phylum to the genus level are reported in Table 6 .

Of the 31 OTU identified in the FDR analysis, 11 were identified from the controls and 3,5, 9, and 3 from the grain, grain + fructose, grain + histidine, and grain 

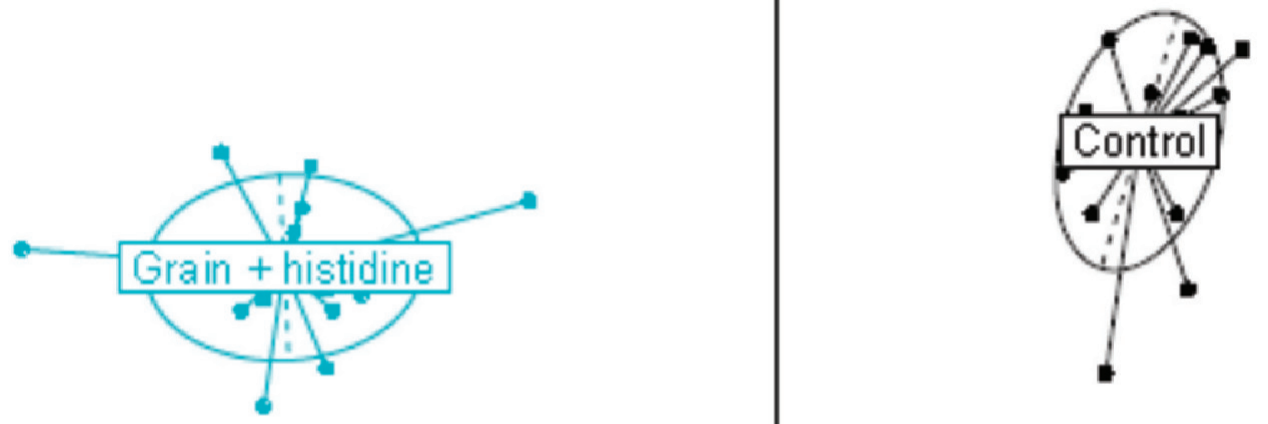

PC1: $28.5 \%$

Figure 2. Constrained between group principal coordinates (PC) analysis of recovered bacterial 16S ribosomal DNA gene sequences at the species level from ruminal fluid collected over approximately a 3.6-h period after heifers consumed the following challenge rations: (1) control (no grain), (2) grain $(1.2 \%$ of BW DMI), (3) grain $(1.2 \%$ of BW DMI) + histidine ( $6 \mathrm{~g} / \mathrm{head}),(4)$ grain $(0.8 \%$ of BW DMI $)+$ fructose $(0.4 \%$ of BW DMI), or (5) grain $(0.8 \%$ of BW DMI $)+$ fructose $(0.4 \%$ of BW DMI $)+$ histidine $(6 \mathrm{~g} /$ head $)$. Number of heifers $=6 /$ group; no. of samples $=18$ /group. Each point on the plot represents the bacterial community composition of a single sample (cow by group by sample time combination), with a greater distance between points indicating a greater difference in bacterial community composition. Color version available in the online PDF.

+ fructose + histidine groups, respectively. The majority of OTU influenced from the control group belonged to the Lachnospiraceae family and Bacteroidales order. The majority of OTU for the grain group belonged to the Bacteroidales order, whereas those identified from the treatment groups that received combinations of grain, fructose, and histidine were more diverse and from the Lactobacillales, Bacteroidales, and Clostridia- les orders and CW040 from the TM7 phylum. An OTU closely related to Streptococcus bovis (OTU no. 4102) had the highest mean value of the OTU for the heifers from the grain + fructose group and was also increased in the grain + fructose + histidine group (Table 6 ).

Operational taxonomic unit no. 1075, identified from the grain + fructose heifers, also had one of the highest mean relative abundances of the identified OTU 


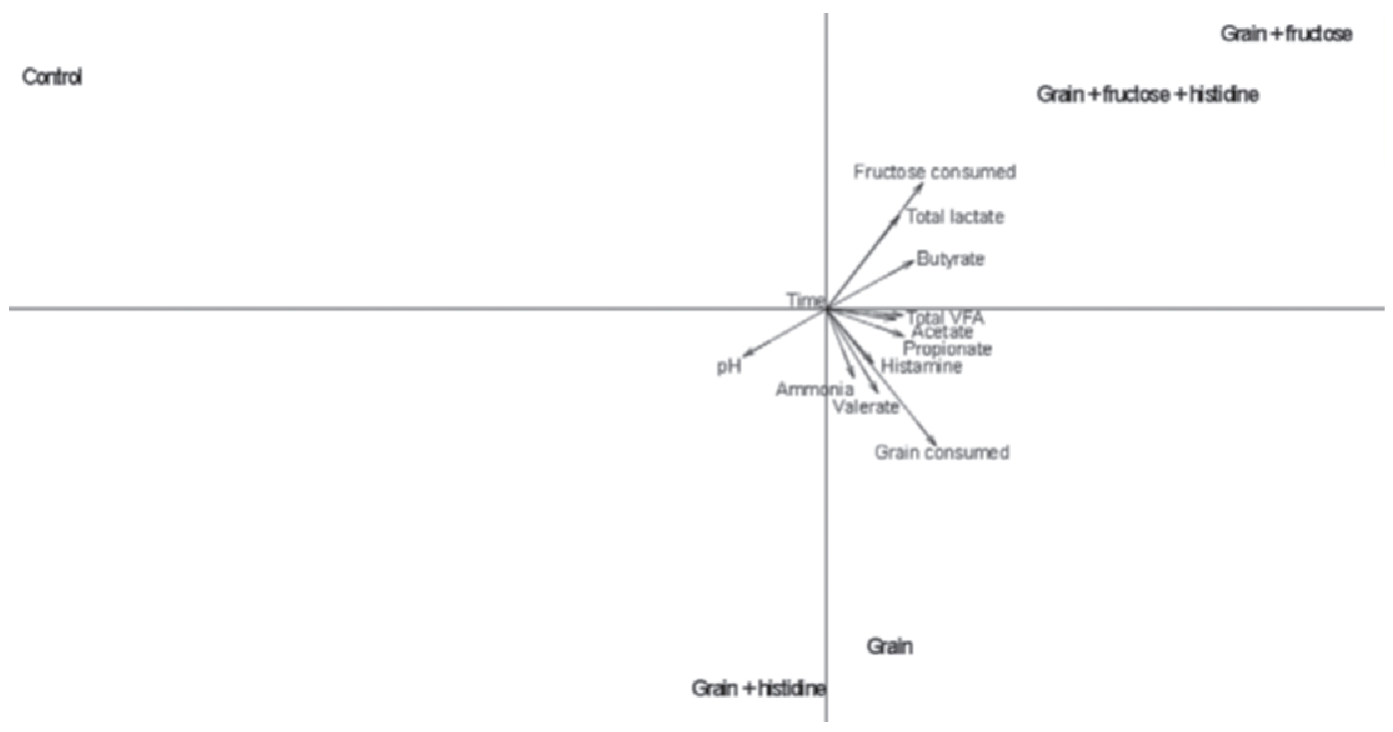

Figure 3. Duality diagram of co-inertia analysis of ruminal bacterial communities from recovered $16 \mathrm{~S}$ ribosomal DNA 454 pyrosequences, measures of ruminal fermentation, and percentages of offered grain and fructose from heifers that consumed the following single challenge rations: (1) control (no grain), (2) grain (1.2\% of BW DMI), (3) grain (1.2\% of BW DMI) + histidine (6 g/head), (4) grain (0.8\% of BW DMI) + fructose $(0.4 \%$ of BW DMI), or (5) grain $(0.8 \%$ of BW DMI $)+$ fructose $(0.4 \%$ of BW DMI $)+$ histidine $(6 \mathrm{~g} /$ head $)$. Number of heifers $=6 /$ group. Ruminal fluid was collected over approximately a 3.6-h period (no. of samples $=18$ /group). On the biplot, the ruminal fermentation measures are represented as arrows. The direction of the arrow of each ruminal fermentation measure indicates an increasing concentration of that measure. The angle between the arrows indicates their degree of correlation. The magnitude of the arrows indicates the importance of the measure on the bacterial community composition. Measures with long arrows are more strongly correlated with the ordination axes than short arrows and have a greater influence on the pattern of variation (Carberry et al., 2012).

and was most closely related to Levilinea saccharolytica strain KIBI- ${ }^{\mathrm{T}}$ (Yamada et al., 2006). Two OTU that differed in the grain + histidine heifers were members of the TM7 phylum and were related to the oral I025 TM7 phylum clone (Table 6).

\section{DISCUSSION}

This study showed that changes in BCC occurred in forage-fed cattle within approximately $3.6 \mathrm{~h}$ of exposure to a single, substantial, non-life-threatening challenge with grain, fructose, or histidine, and combinations of these, and were associated with ruminal fermentation measures. This novel comparison of ruminal bacterial community change over the initial period after consumption of rations shows the rumen ecosystem can rapidly respond to and buffer abrupt changes in readily fermentable substrate.

The treatment group diets were designed to represent the dietary changes that dairy cattle may be exposed to during the transition period. Effects of the treatment groups on ruminal fermentation, endotoxin, and oxidative stress measures are discussed in Golder et al. (2012) and Golder et al. (2013). Collection of ruminal fluid using a stomach tube is not likely to have influenced bacterial variation, as sampling site and method had little effect on bacterial diversity assessment in other studies (Li et al., 2009; Lodge-Ivey et al., 2009), and all treatment groups were exposed to the same method of collection. However, the authors Li et al. (2009) and Lodge-Ivey et al. (2009) used PCR denaturing gradient gel electrophoresis. Different responses may occur in particulate bacteria as opposed to those in the liquid phase of the rumen, which possibly predominated in our study.

The bacteria Lactobacillus spp. and Megasphaera elsdenii that are commonly associated with the onset or prevention of ruminal acidosis, respectively, and belong to the Firmicutes phylum (Hungate, 1966; Bergey et al., 2011), were not identified as one of the 31 OTU that differed in the FDR analysis. However, S. bovis was associated and became more prevalent in heifers fed fructose, indicating that $S$. bovis rapidly responds to the change in diet and forms the initial changes to the ruminal microbiome when unadapted cattle are fed single, abrupt exposures to readily fermentable carbohydrates.

The large among- and within-group variation in bacterial communities, indicated in the constrained between-group $\mathrm{PCoA}$, is consistent with the considerable diversity in bacterial populations in ruminants fed the same diets (Brulc et al., 2009; Li et al., 2009; Chen et al., 2012). However, the bacterial phyla and families that dominated the rumen were consistent among 

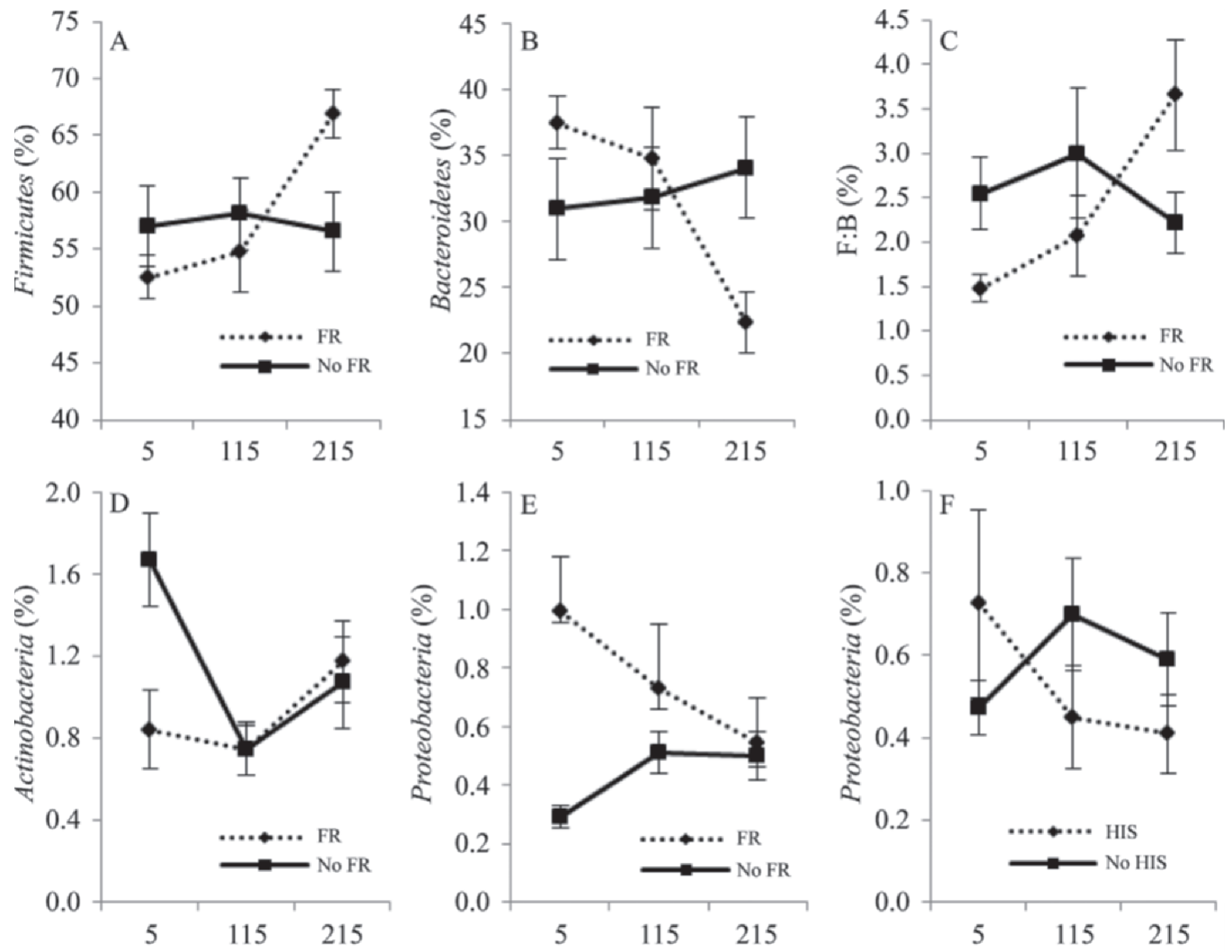

Time (min after consumption)

Figure 4. Ruminal bacterial phyla that had significant $(P<0.005)$ interactions over time. Values are expressed as percentage of relative abundance (predicted mean \pm SEM) of the following ruminal bacterial phyla for fructose- and non-fructose-fed heifers 5 , 115 , and 215 min after consumption of their challenge rations: Firmicutes (A), Bacteroidetes (B), Firmicutes:Bacteroidetes (F:B; C), Actinobacteria (D), Proteobacteria (E), and Proteobacteria in histidine- and non-histidine-fed heifers (F). FR = fructose; HIS = histidine.

treatment groups. This supports the concept that the rumen ecosystem is host specific but comprises a core rumen microbiome (Hernandez-Sanabria et al., 2010; Jami and Mizrahi, 2012) that has a unique ability to adapt to different substrates and may contribute to a host's individual susceptibility to disorders such as ruminal acidosis. Further, Weimer et al. (2010) showed that when $>95 \%$ of ruminal fluid with differing $\mathrm{pH}$, total VFA concentration, and BCC from 2 cows fed the same diet was exchanged, the ruminal $\mathrm{pH}$ and total VFA of the 2 cows returned to their original profiles within $24 \mathrm{~h}$ and BCC returned to near original profiles in $14 \mathrm{~d}$ for one cow and $61 \mathrm{~d}$ for the second. Significant changes in relative abundances in our study occurred among treatment groups for some bacterial phyla and families; the variation resulted in only numerical changes for others. Variation in bacterial communities between cattle may pose difficulties for control of ruminal acidosis and emphasizes the need for large numbers of cattle for in vivo studies. Chen et al. (2012) identified different biodiversity and differing total bacterial copy number of $16 \mathrm{~S}$ rRNA genes between ruminal acidosisresistant and -susceptible cattle. Those findings (Chen et al., 2012) and findings of the current study suggest that opportunities may exist to select for cattle with particular BCC to, for example, reduce the risk of ru- 

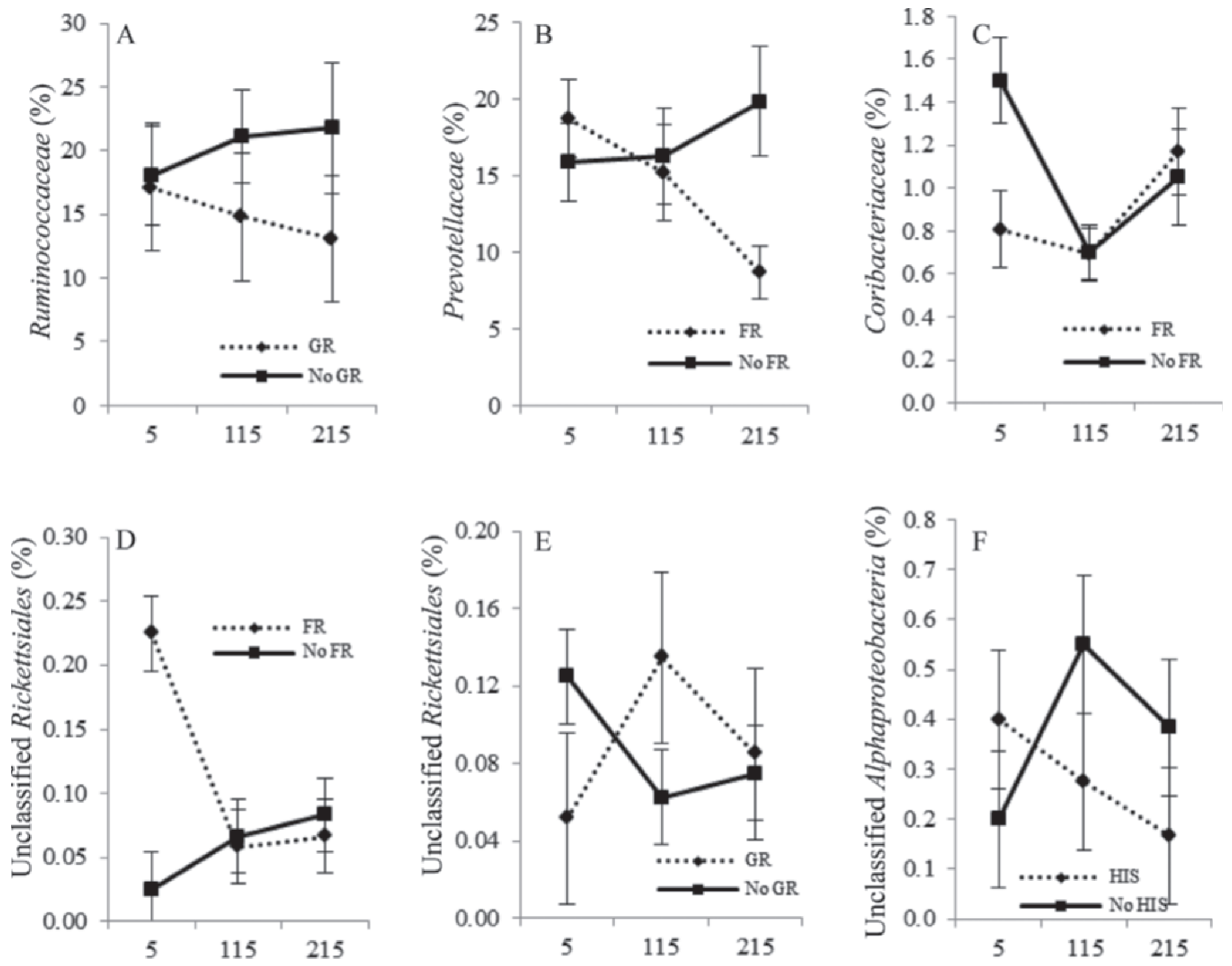

Time (min after consumption)

Figure 5. Ruminal bacterial families that had significant $(P<0.005)$ interactions over time. Values are expressed as percentage of relative abundance (predicted mean $\pm \mathrm{SEM}$ ) of the following ruminal bacterial families 5, 115, and 215 min after consumption of their challenge rations: Ruminococcaceae in grain- and non-grain-fed (control) heifers (A), Prevotellaceae in fructose- and non-fructose-fed heifers (B), Coriobacteriaceae in fructose- and non-fructose-fed heifers (C), unclassified Rickettsiales in fructose- and non-fructose-fed heifers (D), unclassified Rickettsiales in grain- and non-grain-fed (control) heifers (E), and unclassified Alphaproteobacteria in histidine- and non-histidine-fed heifers $(\mathrm{F})$. GR $=$ grain (no GR is the control); FR = fructose; HIS = histidine.

minal acidosis. The variation also suggests that diets and preventive strategies may be most effective when tailored to individual cattle.

Bacteria from the Bacteroidetes (predominately gram negative) and Firmicutes phyla (predominately gram positive) dominated the core microbiome in all cattle, consistent with other studies (Tajima et al., 2000; Kong et al., 2010). The most well-studied members of the Bacteroidetes are those from the Bacteroidia class and include the Prevotella genus, which was the dominant genus in the current study, consistent with other stud- ies feeding various forages and concentrates at different ratios (Tajima et al., 2000; Fernando et al., 2010; Jami and Mizrahi, 2012). The large genetic diversity of Prevotella and their capacity to selectively utilize a large variety of substrates (sugars, starches, hemicellulose, pectin, proteins, amino acids, and peptides) allows them to dominate a range of diets and to thrive in the predominately liquid phase of the rumen that was collected.

The presence of the gram-positive candidate phylum TM7 as the third most prevalent phylum is of inter- 
Table 6. Operational taxonomic units (OTU) that differ by mean relative abundance among treatment groups identified by false discovery rate analysis

Treatment group relative mean abundance ${ }^{1}\left(\times 10^{-3} ; \%\right)$

OTU GR + FR

\begin{tabular}{|c|c|c|c|c|c|}
\hline No. & Control & GR & GR + HIS & + HIS & Group $^{2}$ \\
\hline
\end{tabular}

$\begin{array}{llllll}55 & 4.8 \times 10^{-3} & 5.7 \times 10^{-4} & 8.2 \times 10^{-4} & 9.8 \times 10^{-4} & 1.8 \times 10^{-3}\end{array}$ Control

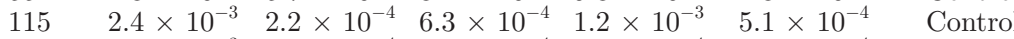

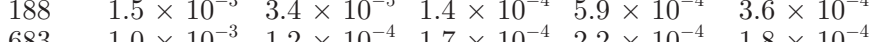

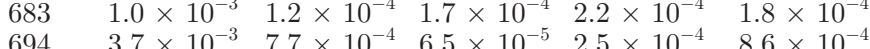

$\begin{array}{lllll}694 & 3.7 \times 10^{-3} \quad 7.7 \times 10^{-4} & 6.5 \times 10^{-5} & 2.5 \times 10^{-4} & 8.6 \times 10^{-4}\end{array}$

$\begin{array}{llllll}771 & 6.9 \times 10^{-3} & 1.6 \times 10^{-5} & 1.0 \times 10^{-4} & 1.8 \times 10^{-4} & 2.2 \times 10^{-4} \\ 1047 & 6.0 \times 10^{-4} & 4.0 \times 10^{-5} & 9.9 \times 10^{-5} & 1.8 \times 10^{-4} & 8.3 \times 10^{-5}\end{array}$

$1047 \quad 6.0 \times 10^{-4} 4.0 \times 10^{-5} \quad 9.9 \times 10^{-5} 1.8 \times 10^{-4}-8.3 \times 10^{-5}$

$20104.2 \times 10^{-3}-5.5 \times 10^{-4} 4.4 \times 10^{-4} 4.5 \times 10^{-4} \times 1.3 \times 10^{-3}$

$\begin{array}{llllll}6567 & 8.9 \times 10^{-4} & 2.0 \times 10^{-4} & 3.8 \times 10^{-5} & 7.5 \times 10^{-5} & 1.9 \times 10^{-4} \\ 39 & 2.2 \times 10^{-4} & 7.4 \times 10^{-3} & 1.1 \times 10^{-4} & 4.3 \times 10^{-5} & 7.0 \times 10^{-4}\end{array}$

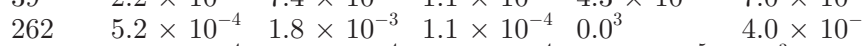

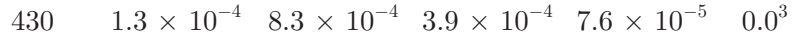

Control

Control

Control

Control

Control

Control

Control

Control

Grain

Grain

$\underline{-}$

Phylum Class

Bacteroidetes Bacteroidia

Bacteroidetes Bacteroidia

Firmicutes Clostridia

Bacteroidetes Bacteroidia

Bacteroidetes Bacteroidia

Bacteroidetes Bacteroidia

Bacteroidetes Bacteroidia

Firmicutes Clostridia

Bacteroidetes Bacteroidia

Bacteroidetes Bacteroidia

Firmicutes Clostridia

Grain + fructose Grain + fructose

Grain + fructose

Grain + fructose

Grain + fructose

Grain + histidin

Grain + histidin

Bacteroidetes Bacteroidia

TM7

Chloroflexi $\quad$ Anaerolinea

TM7

$\begin{array}{ll}\text { TM7 } & \text { TM7-3 } \\ \text { Firmicutes } & \text { Clostridia }\end{array}$

Grain + histidine

Grain + histidine

Grain + histidine

Grain + histidine

Grain + histidine

Grain + histidine

Grain + fructose

+ histidine

Grain + fructose

+ histidine

Grain + fructose + histidine

\section{Firmicutes Clostridia}

Bacteroidetes Bacteroidia

irmicutes Clostridia

Firmicutes Clostridia

Firmicutes Clostridia

TM7

Firmicutes

Clostridia

TM7-3.

Firmicutes Clostridia

Firmicutes Clostridia
Taxonomic assignment Firmicutes Clostridia

Firmicutes Clostridia
Order

Bacteroidales

Bacteroidales

Clostridiales

Bacteroidales

Clostridiales

Bacteroidales

Bacteroidales

Clostridiales

Clostridiales

Bacteroidales

Bacteroidales

Clostridiales

Bacteroidales

CW040

Clostridiales

Anaerolineales

Lactobacillales

CW040

Clostridiales

Clostridiales

Bacteroidales

Clostridiales

Clostridiales

Clostridiales

Clostridiales

CW040

Clostridiales

Clostridiales

Clostridiales
Family

Lachnospiraceae

nassigned

Unassigned

Ruminococcaceae

Prevotellaceae

Lachnospiraceae

Unassigned

Prevotellaceae

Lachnospiraceae

Lachnospiraceae

Unassigned

Unassigned

Clostridiales

Family XIII

incertae sedis

Unassigned

F16

achnospiracea

naerolinaceae

F16

Clostridiales

Family XIII

incertae sedis

Unassigned

Prevotellaceae

Ruminococcaceae

Lachnospiraceae

Lachnospiracea

F16

Lachnospiraceae

Unassigned

Ruminococcaceae
Genus

Unassigned

Unassigned

Unassigned

Prevotella

Unassigned

Unassigned

Prevotella

Unassigned

Unassigned

Unassigned

Unassigned

Unassigned

Unassigned

Unassigned

Coprococcus

SHD-231

Streptococcus

Unassigned

Unassigned

Unassigned

Prevotella

Unassigned

Unassigned

Unassigned

Unassigned

Unassigned

Butyrivibrio

Unassigned

Unassigned

${ }^{1}$ Control (no grain); GR = grain (crushed triticale; $1.2 \%$ of BW DMI); GR + FR = grain (0.8\% of BW DMI) + fructose $(0.4 \%$ of BW DMI); GR + HIS $=$ grain $(1.2 \%$ of BW DMI

+ histidine $(6 \mathrm{~g} / \mathrm{head}) ; \mathrm{GR}+\mathrm{FR}+\mathrm{HIS}=$ grain $(0.8 \%$ of BW DMI $)+$ fructose $(0.4 \%$ of BW DMI $)+$ histidine $(6 \mathrm{~g} / \mathrm{head})$.

${ }^{2}$ Treatment group to which the OTU is associated.

${ }^{3}$ Zero or not detected. 
est. It had a raw mean relative abundance of $>2.5$-fold higher in the grain + histidine-fed cattle compared with controls; however, its relative abundance was not affected by specific substrates in the partial factorial analysis. The TM7 candidate phyla members are found in many ecosystems but, to date, cannot be cultured; they were originally described in soil, aquatic environments, sludge reactors, and, more recently, in periodontitis and inflammatory bowel disease (Rheims et al., 1996; Hugenholtz et al., 2001; Brinig et al., 2003; Kuehbacher et al., 2008). The TM7 members have also been identified in dairy cattle studies (Khafipour et al., 2009; Kong et al., 2010; Hook et al., 2011; Golder et al., 2014). Knowledge of TM7 substrate utilization and end products are limited but recent genome assemblies from metagenomic data suggest a limited fermentative pathway producing lactate and acetate (Albertsen et al., 2013). Lactate values in the dairy cattle fed histidine were not elevated even though TM7 numbers increased $>2.5$ fold. Genomes assembled for TM7 are small and suggest either genome reduction or a reliance on other organisms for key biosynthetic pathways (Kantor et al., 2013). Six Clostridiales and a Bacteroidales bacteria also associated with the histidine treatment showed a similar pattern in abundance changes between the treatments to that of the TM7 OTU. We will use correlation networks to further investigate this and may provide some evidence of a symbiotic relationship.

The Proteobacteria were lower in relative abundance than generally reported in dairy cattle (Tajima et al., 1999, 2000). Abundances of Proteobacteria can be very variable (Jami and Mizrahi, 2012) and differences in diet between this and other studies may account for the relatively low abundance of this gram-negative phylum. The increase in relative abundance of the Proteobacteria in the fructose-fed heifers is consistent with the association between dietary sugar and the relative abundance of the genus Desulfobulbus, belonging to the Proteobacteria phylum (Thoetkiattikul et al., 2013). Escherichia coli, a member of the Proteobacteria, which can be responsible for endotoxin release and has been associated with SARA induced by grain or alfalfa hay (Khafipour et al., 2009), were not identified (or were at levels below those detected by pyrosequencing), which is consistent with the lack of treatment group effect on ruminal endotoxin concentrations in these heifers (Golder et al., 2013).

The phylum Fibrobacteres, considered to be critical for fiber degradation, had a relative abundance below our reported threshold. Fibrobacter species are often underrepresented in $16 \mathrm{~S}$ rDNA libraries from rumen environments (Tajima et al., 1999; Tajima et al., 2000; Tajima, 2001). An absence of this bacterial phylum in beef steers on a restricted diet of medium-quality grass- legume hay (Brulc et al., 2009) and detection in only half of the samples from cattle fed a prolonged diet of $30 \%$ roughage and 70\% concentrate (Jami and Mizrahi, 2012 ) supports our findings. With reduced forage material in the rumen due to the low NDF of our challenge diets and the 14-h period of diet withholding before challenge, the rumen samples collected contained only small particulate matter and predominately fluid. It is plausible that Fibrobacter species would be in higher relative abundance on a targeted investigation of the solid material remaining in the rumen.

The large percentage of bacteria from the Clostridiales and Bacteroidales orders that were not classified to the family level is consistent with others (de Menezes et al., 2011; Thoetkiattikul et al., 2013). It emphasizes that despite the rapidly advancing field of rumen microbiology, the diversity of bacteria that remain uncultured and unidentified is large and it is very possible that several of these bacteria are involved in ruminal acidosis.

The predominance of members of the Prevotellaceae, Ruminococcaceae, and Lachnospiraceae families is consistent with other bovine studies (de Menezes et al., 2011; Thoetkiattikul et al., 2013). The members of the Prevotellaceae family are gram-negative bacteria that belong to the Bacteroidetes phylum and can utilize a range of substrates (Boone et al., 2011), whereas members of the Ruminococcaceae and Lachnospiraceae families belong to the Firmicutes phylum and are largely cellulolytic and fibrolytic bacteria, respectively (Thoetkiattikul et al., 2013). The trend toward a decrease in relative abundance of Lachnospiraceae in the fructosefed heifers is not consistent with the large increase in abundance of this bacterial family between cattle with mild and severe grain-induced ruminal acidosis (Khafipour et al., 2009). This difference may reflect substrate differences between our study and that of Khafipour et al. (2009) and our short 3.6-h sampling period after consumption of the challenge ration.

Ruminal BCC was associated with ruminal fermentation, consistent with others (Hernandez-Sanabria et al., 2010; Carberry et al., 2012). However, dietary effects on $\mathrm{BCC}$ have not always occurred, even when production effects were evident (Mullins et al., 2013). Mohammed et al. (2012) reported that shifts in BCC were not related to total VFA concentrations or individual proportions of VFA, milk yield, and milk composition results, DMI, or severity of ruminal acidosis in cows in the transition period. However, dietary changes in the study by Mohammed et al. (2012) were more subtle than those in the current study. The association between the bacterial communities in the fructose-fed heifers and increased ruminal concentrations of butyrate and lactate suggest that fructose promotes bacterial com- 
munities that lead to less favorable ruminal conditions and an increased risk of ruminal acidosis within a short time after exposure. The grain was likely to have been fermented more slowly than the fructose (Firkins, 2011; Golder et al., 2012) by existing bacterial communities associated with increased ruminal valerate, ammonia, and histamine concentrations, as minimal effects of the relative abundance of bacterial phyla and families were observed between the grain-fed heifers and the controls. Limited literature exists on the effects of sugars on bacterial composition; however, approximately half the amount of glucose is required to induce clinical ruminal acidosis compared with grain (Nagaraja and Titgemeyer, 2007). The relative abundances of gramnegative bacteria are proposed to be replaced with abundances of gram-positive bacteria during ruminal acidosis (Nagaraja and Titgemeyer, 2007), which may explain the increase in the Firmicutes-to-Bacteroidetes ratio in the fructose-fed heifers and the absence of effect in the grain-fed heifers. The rumen appears to be better adapted to changes in grain than sugar and diets with high sugar content should be approached with caution.

Fructose is a substrate for fermentation for most heterofermentative Lactobacillus spp., which produce at least half of their end product carbon as lactate (Schleifer, 2009); hence, the relative abundance of the Lactobacillaceae family was anticipated to increase in the fructose-fed heifers, which did not occur. Similarly, Lactobacillus spp. were not identified as similarity matches to OTU that differed among groups. The decline in lactate production over the sampling period (Golder et al., 2012) and ruminal $\mathrm{pH}>6.0$ may indicate that ruminal conditions were not conducive to the growth of Lactobacillus, as proliferation generally occurs at $\mathrm{pH}<5.0$ (Schleifer, 2009). The short time frame during which sampling occurred after consumption of the challenge ration may have also contributed to lack of change and could suggest that lactobacilli do not have a major role in lactate production in the initial hours after substrate intake in unadapted cattle. Other bacteria that can produce lactate, such as Levilinea, were identified as shifting in relative abundance and could have a role in the pathogenesis of ruminal acidosis.

The increase in relative abundance of the Streptococcaceae in the fructose-fed heifers and the identification of OTU no. 4102, which is closely related to S. bovis, is consistent with the increase in concentrations of $\mathrm{D}$ and L-lactate and ruminal $\mathrm{pH}$ above 6 in these heifers and increased abundances of this bacterial family in dairy cattle during the transition period (Wang et al., 2012). The increase in relative abundance of the Streptococcaceae in the fructose-fed heifers over time is consistent with the known rapid growth rate of $S$. bovis when readily fermentable carbohydrates are available (Russell and Robinson, 1984). Streptococcus bovis has been suggested to be the causative agent of ruminal acidosis; however, S. bovis, has not always increased or even been identified in grain-fed cattle (Tajima et al., 2000; Klieve et al., 2003), and is not always the main cause of ruminal acidity (Hungate, 1966). It has also not been studied when sugars are fed.

The mesophilic Levilinea saccharolytica strain KIBI$1^{\mathrm{T}}$, to which OTU no. 1075 from the grain + fructose group is related, can utilize fructose and produce acetate, pyruvate, hydrogen, and small amounts of lactate as its major fermentation products on a medium with glucose $(20 \mathrm{mM})$ and yeast extract $(0.1 \%$; Yamada et al., 2006). Hence, this organism may have contributed to the increase in concentrations of ruminal D- and Llactate and the trend toward increased concentrations of ruminal acetate $(P=0.065)$ in the fructose groups and the highest D- and L-lactate concentrations in the grain + fructose group of heifers (Golder et al., 2012). However, OTU no. 1075, identified as increasing, is only distantly related to the Levilinea genus.

The Victivallaceae family require sugars to grow (Janssen and Hedlund, 2011), which explains their increase in relative abundance in the fructose-fed heifers. The sole genus of this family, Victivallis, can use fructose as its only energy and carbon source and produces acetate, ethanol, $\mathrm{H}_{2}$, and bicarbonate as fermentation products from glucose (Janssen and Hedlund, 2011).

The increase in relative abundance of bacteria from the Veillonellaceae family in the fructose-fed heifers and these heifers over time was anticipated, given that these heifers had the highest concentrations of ruminal lactate (Golder et al., 2012). Some species belonging to this family, such as Megasphaera elsdenii, Selenomonas ruminantium, and Veillonella parvula, utilize lactate (Stewart et al., 1997); however, the Megasphaera and Veillonella genera were not detected and Selenomonas were present in very low abundance. These lactateutilizing species increase with adaptation to readily fermentable carbohydrate diets (Huber, 1976), which may explain their absence from our samples that were collected from unadapted cattle. Thus, unadapted cattle are likely to be at a higher risk of accumulation of lactate and risk of ruminal acidosis than those adapted to substrates.

The changes in bacterial community in the histidine-fed heifers were greater than suggested from the minimal responses in ruminal fermentation measures. The increase in the relative abundance of the unclassified Clostridiales appeared responsible for the shift in bacterial community within these heifers. Perhaps several bacteria from this order can utilize histidine to produce a range of fermentation products, which are 
subsequently utilized by other bacteria, explaining the absence of effects on ruminal fermentation measures. It is known that histidine can be fermented to histamine (Garner et al., 2002), acetate, and butyrate (Chen and Russell, 1989). The decrease in relative abundance of bacteria from the Lentisphaerae phylum in the histidinefed groups may reflect an inability of these bacteria to utilize amino acids (Cho et al., 2004).

An increase in histamine-producing bacteria was anticipated, as ruminal histamine concentrations approached a significant increase $(P=0.054)$ in the histidine-fed heifers and were approximately 2-fold higher than those of the controls (Golder et al., 2012). The absence of identification of Allisonella histaminiformans, which solely utilizes histidine as an energy source (Garner et al., 2002), and absence or very low abundance of several other bacteria, such as Lactobacillus spp., Bacterium coli, Clostridium spp., and Proteus spp., which produce histidine decarboxylase that decarboxylates histidine to histamine (Gale, 1940; Gale et al., 1941; Schelp et al., 2001), suggests that these may not be key bacteria involved in histamine generation over the challenge. It is possible that other bacteria are capable of histamine generation and that production of histamine is a sufficiently more widely distributed trait and the role of any single species is limited.

The stronger relationship between histamine concentration and bacterial composition in the grain compared with either histidine-fed group suggests that generation of histamine from grain had a greater influence on BCC than the supplemented histidine over the time period. This is consistent with increased ruminal histamine concentrations in concentrate- compared with hay-fed cattle (Fuquay et al., 1969). The increase in relative abundance of bacteria from the Anaerolinaceae family in the histidine-fed heifers may be of interest. Information on this bacterial family in ruminants is limited; however, casamino acids supported only weak growth of mesophilic strains isolated from an anaerobic sludge blanket (Yamada et al., 2006).

The Anaerovorax genus to which OTU no. 149 is closely related, from the grain + histidine group, are strictly anaerobic chemoorganotrophic bacteria that prefer amino acid derivatives as substrates (Schink, 2009) and have been identified in ruminal samples (Kim et al., 2011). All strains from this genus identified to date fermented only putrescine, 4-aminobutyrate, or 4-hydroxybutyrate as substrates to acetate, butyrate, molecular hydrogen, and ammonia (Matthies et al., 1989, 2000). As Anaerovorax spp. from a non-rumen origin are associated with amino acid degradation and the Anaerovorax genus has been identified from ruminal samples, we propose that it may be associated with histidine degradation in the rumen.
Feeding cycle has been suggested to be the most important factor influencing bacterial community structure, during which intermittent supplies of fermentable energy exist for bacterial growth and catabolism (Welkie et al., 2010). Bacterial populations normally increase after feeding (Bryant and Robinson, 1968) and decline as substrate availability declines as the subsequent feeding approaches (Mullins et al., 2013). Sampling time was a very small vector in the co-inertia analysis, suggesting that it did not have as large an influence on BCC as the fermentation measures. Populations of bacteria and growth activity of bacteria may have changed but were not quantified in terms of absolute abundance in our study.

Although it is a challenge to compare, BCC and relative abundance of bacteria differed from those in longer-term challenge studies where cattle were adapted to diets (Khafipour et al., 2009; Callaway et al., 2010; Golder et al., 2014). It is evident that the BCC of the rumen is capable of rapid responses to abrupt exposures to substrates. We hypothesize that ruminal bacteria involved in the initial onset of the pathogenesis of ruminal acidosis may differ from those involved in the later stages of ruminal acidosis and are likely to differ between adapted and unadapted cattle. Differences in BCC may occur between lactating cows and the heifers such as those in this study.

\section{CONCLUSIONS}

This study uniquely examined short-term changes in ruminal bacteria in cattle offered a single, substantial readily fermentable carbohydrate challenge. It exemplifies the dynamic ability of the rumen to cope with abrupt exposures to large amounts of readily fermentable carbohydrates. Our hypothesis was supported that distinct bacterial communities would develop over 3.6 $\mathrm{h}$ after a single challenge feeding among heifers fed combinations of grain, fructose, and histidine, and reflect ruminal fermentation measures. Although heifers shared a common core microbiome, variation among heifers was large, suggesting that cattle have distinct bacterial communities that may influence their ability to cope with changes in substrate type and amount. Bacterial community composition of the fructose-fed heifers was more diverse and was associated with ruminal fermentation measures that may pose an increased risk of ruminal acidosis relative to grain. Bacterial communities of grain-fed heifers were associated with increased concentrations of ruminal valerate, ammonia, and histamine. We hypothesize that a large number of bacteria may utilize histidine as a substrate. An OTU identified in the fructose-fed cattle was closely associated with $S$. bovis. We did not identify OTU with simi- 
larity to Lactobacillus spp. and Megasphaera elsdenii that differed among treatment groups in this abrupt, single feeding of readily fermentable carbohydrates.

\section{ACKNOWLEDGMENTS}

This work was supported by Dairy Australia (Southbank, VIC, Australia); SBScibus (Camden, NSW, Australia); Dairy NSW (Mudgee, NSW, Australia); CSIRO Animal, Food and Health Services (St. Lucia, QLD, Australia); and The University of Sydney (Camden, NSW, Australia). The authors wish to acknowledge the staff at The CSIRO Animal, Food and Health Services for laboratory assistance; in particular, Vicki Whan.

\section{REFERENCES}

Ahrens, F. A. 1967. Histamine, lactic acid and hypertonicity as factors in the development of rumenitis in cattle. Am. J. Vet. Res. 28:1335-1342.

Albertsen, M., P. Hugenholtz, A. Skarshewski, K. L. Nielsen, G. W. Tyson, and P. H. Nielsen. 2013. Genome sequences of rare, uncultured bacteria obtained by differential coverage binning of multiple metagenomes. Nat. Biotechnol. 31:533-538.

Bergey, D. H., P. De Vos, D. R. Boone, G. M. Garrity, R. W. Castenholz, D. J. Brenner, N. R. Krieg, and J. T. Staley. 2011. Bergey's Manual of Systematic Bacteriology: Volume 3: The Firmicutes. Springer, New York, NY.

Boone, D. R., R. W. Castenholz, G. M. Garrity, and N. R. Krieg. 2011. Bergey's Manual of Systematic Bacteriology: Volume 4: The Bacteroidetes, Spirochaetes, Tenericutes (Mollicutes), Acidobacteria, Fibrobacteres, Fusobacteria, Dictyoglomi, Gemmatimonadetes, Lentisphaerae, Verrucomicrobia, Chlamydiae, and Planctomycetes. Springer, New York, NY.

Bragg, L., G. Stone, M. Imelfort, P. Hugenholtz, and G. W. Tyson. 2012. Fast, accurate error-correction of amplicon pyrosequences using Acacia. Nat. Methods 9:425-426.

Bramley, E., I. J. Lean, W. J. Fulkerson, M. A. Stevenson, A. R. Rabiee, and N. D. Costa. 2008. The definition of acidosis in dairy herds predominantly fed on pasture and concentrates. J. Dairy Sci. 91:308-321.

Brinig, M. M., P. W. Lepp, C. C. Ouverney, G. C. Armitage, and D. A. Relman. 2003. Prevalence of bacteria of division TM7 in human subgingival plaque and their association with disease. Appl. Environ. Microbiol. 69:1687-1694.

Brulc, J. M., D. A. Antonopoulos, M. E. Berg Miller, M. K. Wilson, A. C. Yannarell, E. A. Dinsdale, R. E. Edwards, E. D. Frank, J. B. Emerson, P. Wacklin, P. M. Coutinho, B. Henrissat, K. E. Nelson, and B. A. White. 2009. Gene-centric metagenomics of the fiber-adherent bovine rumen microbiome reveals forage specific glycoside hydrolases. Proc. Natl. Acad. Sci. USA 106:1948-1953.

Bryant, M. P., and I. M. Robinson. 1968. Effects of diet, time after feeding, and position sampled on numbers of viable bacteria in the bovine rumen. J. Dairy Sci. 51:1950-1955.

Callaway, T. R., S. E. Dowd, T. S. Edrington, R. C. Anderson, N. Krueger, N. Bauer, P. J. Kononoff, and D. J. Nisbet. 2010. Evaluation of bacterial diversity in the rumen and feces of cattle fed different levels of dried distillers grains plus solubles using bacterial tag-encoded FLX amplicon pyrosequencing. J. Anim. Sci. 88:3977-3983.

Caporaso, J. G., J. Kuczynski, J. Stombaugh, K. Bittinger, F. D. Bushman, E. K. Costello, N. Fierer, A. G. Pena, J. K. Goodrich, J. I. Gordon, G. A. Huttley, S. T. Kelley, D. Knights, J. E. Koenig, R. E. Ley, C. A. Lozupone, D. McDonald, B. D. Muegge, M. Pirrung, J. Reeder, J. R. Sevinsky, P. J. Turnbaugh, W. A. Walters, J. Widmann, T. Yatsunenko, J. Zaneveld, and R. Knight. 2010.
QIIME allows analysis of high-throughput community sequencing data. Nat. Methods 7:335-336.

Carberry, C. A., D. A. Kenny, S. Han, M. S. McCabe, and S. M. Waters. 2012. Effect of phenotypic residual feed intake and dietary forage content on the rumen microbial community of beef cattle. Appl. Environ. Microbiol. 78:4949-4958.

Chen, G., and J. B. Russell. 1989. More monensin-sensitive, ammoniaproducing bacteria from the rumen. Appl. Environ. Microbiol $55: 1052-1057$

Chen, Y., M. Oba, and L. L. Guan. 2012. Variation of bacterial communities and expression of toll-like receptor genes in the rumen of steers differing in susceptibility to subacute ruminal acidosis. Vet. Microbiol. 159:451-459.

Cho, J.-C., K. L. Vergin, R. M. Morris, and S. J. Giovannoni. 2004. Lentisphaera araneosa gen. nov., sp. nov, a transparent exopolymer producing marine bacterium, and the description of a novel bacterial phylum, Lentisphaerae. Environ. Microbiol. 6:611-621.

Dain, J. A., A. L. Neal, and R. W. Dougherty. 1955. The occurrence of histamine and tyramine in rumen ingesta of experimentally overfed sheep. J. Anim. Sci. 14:930-935.

Danscher, A. M., H. L. Enemark, P. H. Andersen, B. Aalbæk, and O. L. Nielsen. 2010. Polysynovitis after oligofructose overload in dairy cattle. J. Comp. Pathol. 142:129-138.

Danscher, A. M., J. M. D. Enemark, E. Telezhenko, N. Capion, C. T. Ekstrøm, and M. B. Thoefner. 2009. Oligofructose overload induces lameness in cattle. J. Dairy Sci. 92:607-616.

de Menezes, A. B., E. Lewis, M. O'Donovan, B. F. O'Neill, N. Clipson, and E. M. Doyle. 2011. Microbiome analysis of dairy cows fed pasture or total mixed ration diets. FEMS Microbiol. Ecol. $78: 256-265$

Dray, S., and A.-B. Dufour. 2007. The ade4 package: Implementing the duality diagram for ecologists. J. Stat. Softw. 22:1-20.

Fernando, S. C., H. T. Purvis, F. Z. Najar, L. O. Sukharnikov, C. R. Krehbiel, T. G. Nagaraja, B. A. Roe, and U. Desilva. 2010. Rumen microbial population dynamics during adaptation to a high-grain diet. Appl. Environ. Microbiol. 76:7482-7490.

Firkins, J. L. 2011. Liquid feeds and sugars in diets for dairy cattle. Pages 62-80 in Proc. 2011 Florida Rumin. Nutr. Symp., 22nd Annu. Mtg. Univ. Florida, Gainesville.

Fuquay, J. W., E. M. Kesler, and A. Zarkower. 1969. Effect of prepartum and postpartum diet on histamine metabolism of young Holstein cows. J. Dairy Sci. 52:1781-1785.

Gale, E. F. 1940. The production of amines by bacteria I. The decarboxylation of amino-acids by strains of Bacterium coli. Biochem. J. 34:392-413.

Gale, E. F., G. L. Brown, F. C. MacIntosh, and P. B. White. 1941. Production of amines by bacteria 4 . The decarboxylation of amino-acids by organisms of the groups Clostridium and Proteus. Biochem. J. 35:66-80.

Garner, M. R., J. F. Flint, and J. B. Russell. 2002. Allisonella histaminiformans gen. nov., sp. nov. A novel bacterium that produces histamine, utilizes histidine as its sole energy source, and could play a role in bovine and equine laminitis. Syst. Appl. Microbiol. 25:498-506.

Golder, H. M., P. Celi, A. R. Rabiee, C. Heuer, E. Bramley, S. W. Miller, R. King, and I. J. Lean. 2012. Effects of grain, fructose and histidine on ruminal $\mathrm{pH}$ and fermentation products during an induced subacute acidosis protocol. J. Dairy Sci. 95:1971-1982.

Golder, H. M., S. E. Denman, C. McSweeney, W. J. Wales, M. J. Auldist, M. M. Wright, L. C. Marett, J. S. Greenwood, M. C. Hannah P. Celi, E. Bramley, and I. J. Lean. 2014. Effects of partial mixed rations and supplement amounts on milk production and composition, ruminal fermentation, bacterial communities, and ruminal acidosis. J. Dairy Sci. 10.3168/jds.2014-8049.

Golder, H. M., I. J. Lean, A. R. Rabiee, R. King, and P. Celi. 2013 Effects of grain, fructose, and histidine feeding on endotoxin and oxidative stress measures in dairy heifers. J. Dairy Sci. 96:78817891

Gozho, G. N., J. C. Plaizier, D. O. Krause, A. D. Kennedy, and K. M. Wittenberg. 2005. Subacute ruminal acidosis induces ruminal 
lipopolysaccharide endotoxin release and triggers an inflammatory response. J. Dairy Sci. 88:1399-1403.

Heldt, J. S., R. C. Cochran, G. L. Stokka, C. G. Farmer, C. P. Mathis, E. C. Titgemeyer, and T. G. Nagaraja. 1999. Effects of different supplemental sugars and starch fed in combination with degradable intake protein on low-quality forage use by beef steers. J. Anim. Sci. 77:2793-2802.

Hernandez-Sanabria, E., L. L. Guan, L. A. Goonewardene, M. Li, D. F. Mujibi, P. Stothard, S. S. Moore, and M. C. Leon-Quintero. 2010. Correlation of particular bacterial PCR-denaturing gradient gel electrophoresis patterns with bovine ruminal fermentation parameters and feed efficiency traits. Appl. Environ. Microbiol. 76:6338-6350.

Hook, S. E., M. A. Steele, K. S. Northwood, J. Dijkstra, J. France, A.-D. G. Wright, and B. W. McBride. 2011. Impact of subacute ruminal acidosis (SARA) adaptation and recovery on the density and diversity of bacteria in the rumen of dairy cows. FEMS Microbiol. Ecol. 78:275-284.

Huber, T. L. 1976. Physiological effects of acidosis on feedlot cattle. J. Anim. Sci. 43:902-909.

Hugenholtz, P., G. W. Tyson, R. I. Webb, A. M. Wagner, and L. L. Blackall. 2001. Investigation of candidate division TM7, a recently recognized major lineage of the domain bacteria with no known pure-culture representatives. Appl. Environ. Microbiol. 67:411419.

Hughes, J. B., J. J. Hellmann, T. H. Ricketts, and B. J. M. Bohannan. 2001. Counting the uncountable: Statistical approaches to estimating microbial diversity. Appl. Environ. Microbiol. 67:4399-4406.

Hungate, R. E. 1966. The Rumen and Its Microbes. Academic Press Inc., New York, NY.

Jami, E., and I. Mizrahi. 2012. Composition and similarity of bovine rumen microbiota across individual animals. PLoS ONE 7:e33306.

Janssen, P. H., and B. P. Hedlund. 2011. Family I. Victivallaceae fam. nov. Pages 795-799 in Bergey's Manual of Systematic Bacteriology. Vol. 4. N. R. Krieg, J. T. Staley, B. P. Hedlund, B. J. Paster, N. Ward, W. Ludwig, and W. B. Whitman, ed. Springer Verlag, New York, NY.

Kantor, R. S., K. C. Wrighton, K. M. Handley, I. Sharon, L. A. Hug, C. J. Castelle, B. C. Thomas, and J. F. Banfield. 2013. Small genomes and sparse metabolisms of sediment-associated bacteria from four candidate phyla. MBio 4:e00708-e00713.

Khafipour, E., S. Li, J. C. Plaizier, and D. O. Krause. 2009. Rumen microbiome composition determined using two nutritional models of subacute ruminal acidosis. Appl. Environ. Microbiol. $75: 7115-7124$.

Kim, M., M. Morrison, and Z. Yu. 2011. Status of the phylogenetic diversity census of ruminal microbiomes. FEMS Microbiol. Ecol. $76: 49-63$

Klieve, A. V., D. Hennessy, D. Ouwerkerk, R. J. Forster, R. I. Mackie, and G. T. Attwood. 2003. Establishing populations of Megasphaera elsdenii YE 34 and Butyrivibrio fibrisolvens YE 44 in the rumen of cattle fed high grain diets. J. Appl. Microbiol. 95:621-630.

Kong, Y., R. Teather, and R. Forster. 2010. Composition, spatial distribution, and diversity of the bacterial communities in the rumen of cows fed different forages. FEMS Microbiol. Ecol. 74:612-622.

Kuehbacher, T., A. Rehman, P. Lepage, S. Hellmig, U. R. Fölsch, S. Schreiber, and S. J. Ott. 2008. Intestinal TM7 bacterial phylogenies in active inflammatory bowel disease. J. Med. Microbiol. 57:1569-1576.

Lane, D. J. 1991. 16S/23S rRNA sequencing. Pages 115-175 in Nucleic acid Techniques in Bacterial Systematics. Vol. 4. E. Stackebrandt and M. Goodfellow, ed. John Wiley \& Son Ltd., New York, NY.

Li, M., G. B. Penner, E. Hernandez-Sanabria, M. Oba, and L. L. Guan. 2009. Effects of sampling location and time, and host animal on assessment of bacterial diversity and fermentation parameters in the bovine rumen. J. Appl. Microbiol. 107:1924-1934.

Lodge-Ivey, S. L., J. Browne-Silva, and M. B. Horvath. 2009. Technical note: Bacterial diversity and fermentation end products in rumen fluid samples collected via oral lavage or rumen cannula. J. Anim. Sci. 87:2333-2337.
Ludwig, W., O. Strunk, R. Westram, L. Richter, H. Meier, Yadhukumar, A. Buchner, T. Lai, S. Steppi, G. Jobb, W. Förster, I. Brettske, S. Gerber, A. W. Ginhart, O. Gross, S. Grumann, S. Hermann, R. Jost, A. König, T. Liss, R. Lüßmann, M. May, B. Nonhoff, B. Reichel, R. Strehlow, A. Stamatakis, N. Stuckmann, A. Vilbig, M. Lenke, T. Ludwig, A. Bode, and K. H. Schleifer. 2004. ARB: A software environment for sequence data. Nucleic Acids Res. 32:1363-1371.

Matthies, C., S. Evers, W. Ludwig, and B. Schink. 2000. Anaerovorax odorimutans gen. nov., sp. nov., a putrescine-fermenting, strictly anaerobic bacterium. Int. J. Syst. Evol. Microbiol. 50:1591-1594.

Matthies, C., F. Mayer, and B. Schink. 1989. Fermentative degradation of putrescine by new strictly anaerobic bacteria. Arch. Microbiol. 151:498-505.

Miller, L. A., J. M. Moorby, D. R. Davies, M. O. Humphreys, N. D. Scollan, J. C. Macrae, and M. K. Theodorou. 2001. Increased concentrations of water-soluble carbohydrate in perennial ryegrass (Lolium perenne L.): Milk production from late-lactation dairy cows. Grass Forage Sci. 56:383-394.

Mohammed, R., D. M. Stevenson, P. J. Weimer, G. B. Penner, and K. A. Beauchemin. 2012. Individual animal variability in ruminal bacterial communities and ruminal acidosis in primiparous Holstein cows during the periparturient period. J. Dairy Sci. 95:6716-6730.

Mullins, C. R., L. K. Mamedova, A. J. Carpenter, Y. Ying, M. S. Allen, I. Yoon, and B. J. Bradford. 2013. Analysis of rumen microbial populations in lactating dairy cattle fed diets varying in carbohydrate profiles and Saccharomyces cerevisiae fermentation product. J. Dairy Sci. 96:5872-5881.

Nagaraja, T. G., and E. C. Titgemeyer. 2007. Ruminal acidosis in beef cattle: The current microbiological and nutritional outlook. J. Dairy Sci. 90(E-Suppl.):E17-E38.

O'Grady, L., M. L. Doherty, and F. J. Mulligan. 2008. Subacute ruminal acidosis (SARA) in grazing Irish dairy cows. Vet. J. 176:4449.

Oetzel, G. R., K. V. Nordlund, and E. F. Garrett. 1999. The effect of ruminal $\mathrm{pH}$ and stage of lactation on ruminal concentrations in dairy cows. J. Dairy Sci. 82(Suppl. 1):38-39.

Owens, F. N., D. S. Secrist, W. J. Hill, and D. R. Gill. 1998. Acidosis in cattle: A review. J. Anim. Sci. 76:275-286.

Penkov, D., D. Pavlov, and T. Mihovsky. 2003. Comparative study of the amino acid's true digestibility of different clover (Trifolium) varieties in experiments with ganders. J. Cent. Eur. Agric. 4:191-198.

Petri, R. M., R. J. Forster, W. Yang, J. J. McKinnon, and T. A. McAllister. 2012. Characterization of rumen bacterial diversity and fermentation parameters in concentrate fed cattle with and without forage. J. Appl. Microbiol. 112:1152-1162.

RAGFAR (Reference Advisory Group on Fermentative Acidosis of Ruminants). 2007. Ruminal acidosis-Aetiopathogenesis, prevention and treatment: A review for veterinarians and nutritional professionals. A. V. Association, ed. Blackwell Publishing Asia Pty. Ltd., Carlton, VIC, Australia.

Reeves, M., W. Fulkerson, and R. Kellaway. 1996. Forage quality of kikuyu (Pennisetum clandestinum): The effect of time of defoliation and nitrogen fertiliser application and in comparison with perennial ryegrass (Lolium perenne). Aust. J. Agric. Res. 47:1349-1359.

Rheims, H., F. Rainey, and E. Stackebrandt. 1996. A molecular approach to search for diversity among bacteria in the environment. J. Ind. Microbiol. 17:159-169.

Russell, J. B., and P. H. Robinson. 1984. Compositions and characteristics of strains of Streptococcus bovis. J. Dairy Sci. 67:1525-1531.

Schelp, E., S. Worley, A. F. Monzingo, S. Ernst, and J. D. Robertus. 2001. pH-induced structural changes regulate histidine decarboxylase activity in Lactobacillus 30a. J. Mol. Biol. 306:727-732.

Schink, B. 2009. Genus I. Anaerovorax. Pages 1154-1155 in Bergey's Manual of Systematic Bacteriology: Volume 3: The Firmicutes. Vol. 3. P. De Vos, G. M. Garrity, D. Jones, N. R. Krieg, W. Ludwig, F. A. Rainey, K. Schleifer, and W. B. Whitman, ed. Springer, New York, NY. 
Schleifer, K.-H. 2009. Family I. Lactobacillaceae. Pages 463-530 in Bergey's Manual of Systematic Bacteriology: Volume 3: The Firmicutes. Vol. 3. P. De Vos, G. M. Garrity, D. Jones, N. R. Krieg, W. Ludwig, F. A. Rainey, K. Schleifer, and W. B. Whitman, ed. Springer, New York, NY.

Snell-Castro, R., J.-J. Godon, J.-P. Delgenès, and P. Dabert. 2005. Characterisation of the microbial diversity in a pig manure storage pit using small subunit rDNA sequence analysis. FEMS Microbiol. Ecol. 52:229-242.

Stewart, C. S., J. F. Flint, and M. P. Bryant. 1997. The rumen bacteria. Pages 10-72 in The Rumen Microbial Ecosystem. 2nd ed. P. N. Hobson and C. S. Stewart, ed. Blackie Academic and Professional, London, UK.

Stone, W. C. 1999. The effect of subclinical rumen acidosis on milk components. Pages 40-46 in Proc. Cornell Nutrition Conference Feed Manufacturing, Syracuse, NY, Cornell University, Ithaca, NY.

Tajima, K. 2001. Diet-dependent shifts in the bacterial population of the rumen revealed with real-time PCR. Appl. Environ. Microbiol. 67:2766-2774.

Tajima, K., R. I. Aminov, T. Nagamine, K. Ogata, M. Nakamura, H. Matsui, and Y. Benno. 1999. Rumen bacterial diversity as determined by sequence analysis of $16 \mathrm{~s}$ rDNA libraries. FEMS Microbiol. Ecol. 29:159-169.

Tajima, K., S. Arai, K. Ogata, T. Nagamine, H. Matsui, M. Nakamura, R. I. Aminov, and Y. Benno. 2000. Rumen bacterial community transition during adaptation to high-grain diet. Anaerobe 6:273-284.

Tas, B. M., H. Z. Taweel, H. J. Smit, A. Elgersma, J. Dijkstra, and S. Tamminga. 2006. Effects of perennial ryegrass cultivars on milk yield and nitrogen utilization in grazing dairy cows. J. Dairy Sci. 89:3494-3500.

Thoefner, M. B., C. C. Pollitt, A. W. van Eps, G. J. Milinovich, D. J. Trott, O. Wattle, and P. H. Andersen. 2004. Acute bovine laminitis: A new induction model using alimentary oligofructose overload. J. Dairy Sci. 87:2932-2940.

Thoetkiattikul, H., W. Mhuantong, T. Laothanachareon, S. Tangphatsornruang, V. Pattarajinda, L. Eurwilaichitr, and V. Champreda 2013. Comparative analysis of microbial profiles in cow rumen fed with different dietary fiber by tagged $16 \mathrm{~S}$ rRNA gene pyrosequencing. Curr. Microbiol. 67:130-137.

Wang, X., X. Li, C. Zhao, P. Hu, H. Chen, Z. Liu, G. Liu, and Z. Wang. 2012. Correlation between composition of the bacterial community and concentration of volatile fatty acids in the rumen during the transition period and ketosis in dairy cows. Appl. Environ. Microbiol. 78:2386-2392.

Weimer, P. J., D. M. Stevenson, H. C. Mantovani, and S. L. C. Man. 2010. Host specificity of the ruminal bacterial community in the dairy cow following near-total exchange of ruminal contents. J. Dairy Sci. 93:5902-5912.

Welkie, D. G., D. M. Stevenson, and P. J. Weimer. 2010. ARISA analysis of ruminal bacterial community dynamics in lactating dairy cows during the feeding cycle. Anaerobe 16:94-100.

Yamada, T., Y. Sekiguchi, S. Hanada, H. Imachi, A. Ohashi, H. Harada, and Y. Kamagata. 2006. Anaerolinea thermolimosa sp. nov. Levilinea saccharolytica gen. nov., sp. nov. and Leptolinea tardivitalis gen. nov., sp. nov., novel filamentous anaerobes, and description of the new classes Anaerolineae classis nov. and Caldilineae classis nov. in the bacterial phylum Chloroflexi. Int. J. Syst. Evol. Microbiol. 56:1331-1340. 